FACULTY OF BUSINESS ADMINISTRATION AND ECONOMICS

Working Paper Series

Working Paper No. 2019-15

Share price reactions to tariff imposition announcements in the Trump era - An event study of the trade conflict

Sascha Tobias Wengerek

February 2020 


\title{
Share price reactions to tariff imposition announcements in the Trump era - An event study of the trade conflict*
}

\author{
Sascha Tobias Wengerek ${ }^{\dagger}$
}

\begin{abstract}
Employing a unique sample of 2,849 tariff imposition announcements by and against the United States (U.S.) over the period from 2018 to 2019, this study analyzes the impact of recent tariff announcements on share prices from 859 U.S. companies. We provide evidence for negative (cumulative) average abnormal stock returns due to tariff announcements during a symmetric threeday event window. We suggest that stock market investors expect adverse impacts of tariff impositions, e.g. a decrease in the companies' future cash flows and a threat of retaliation. The negative wealth effects are observed irrespective of whether the Trump administration announces safeguard tariffs to protect domestic firms or a retaliation is declared by foreign countries. Moreover, building several subsamples, we find that the adverse impact is mostly driven by announcements involving China and is associated with a variety of sector, tariff, trade and firm characteristics.
\end{abstract}

Keywords: event study, international relations, protectionism, strategic trade policy, tariffs, trade conflict

JEL Classification: F14, F18, F23, F51

*I am grateful to André Uhde, Benjamin Hippert, Sonja Warkulat and Matthias Pelster for their critical remarks and discussions. Finally, I thank Maike Daniel, Sarah Herwald, Nina Klocke and Marcel Lengacher for outstanding research assistance.

†Corresponding author, Paderborn University, Warburger Straße 100, 33098 Paderborn, Germany, phone: +49 5251 605559, fax: +495251 604207, e-mail: sascha.tobias.wengerek@upb.de. 


\section{Introduction}

Since Franklin D. Roosevelt signed the Reciprocal Trade Agreements Act in 1934, and especially after the Second World War, the United States (U.S.) were one of the driving forces to encourage international efforts to reduce trade barriers and integrate markets. The process of opening world markets and expanding trade led to a prosperous international trading system with the U.S. as the world's largest national economy and leading global trader. According to the Office of the U.S. Trade Representative (USTR) and the Peterson Institute for International Economics, in particular the U.S. derived substantial long-term benefits from extensively engaging in international trade, i.e. growth of the labor market, technological progress, increasing living standards and consumer choice. With access to global markets, companies from the U.S. expanded production capacities to serve foreign markets and earned additional revenues by selling their products and services abroad. Furthermore, U.S. companies also improved their productivity, efficiency and competitiveness by importing low priced intermediate goods and high quality inputs (Executive Office of the President of the United States, 2015). Figure 1a remarkably reveals the importance of international trade relations for the American economy, which is indicated by almost continuously increasing U.S. import and export volumes, except during the Global Financial Crisis (2007/2008).

However, since 2018, the Trump administration has reinforced a more restrictive trade policy for several reasons. First, investigations under Section 201 (global safeguard investigations) of the Trade Act of 1974 revealed that large residential washers and crystalline silicon photovoltaic cells are being imported into the U.S. in increased quantities which cause serious damage to the domestic industry (U.S. International Trade Commission, 2017a,b).

Second, the Department of Commerce found that present quantities of steel and aluminum imports weaken the U.S. economy and threaten to impair the national security, as defined by Section 232 (safeguarding national security) of the Trade Expansion Act of 1962 (U.S. Department of Commerce, 2018a,b). 
Third, a wide variety of Chinese unfair acts, policies, and practices, that have harmed American intellectual property rights, innovation, or technology development, was reported under Section 301 of the Trade Act of 1974. The U.S. government criticized China for implementing unreasonable or discriminatory laws, policies and practices supporting the transfer of American technologies and intellectual properties to Chinese entities. Furthermore, the Trump administration complained about Chinese ownership and investment restrictions regarding U.S. firms, especially in cutting-edge technology sectors. From the perspective of the U.S. government, these actions contributed to the annual trade deficit with China and negatively affected American economic interests in terms of lower exports, weaker competitiveness and an increased shifting of jobs to China (Office of the United States Trade Representative, 2018). In addition, the Trump administration accused China of manipulating its currency in order to make Chinese products more competitive in the world markets. As illustrated by Figure 1b, the U.S. experienced monthly bilateral trade deficits with several trading partners, especially with China, which is mostly driven by a savings-investment imbalance and the relative strength of the U.S. dollar (USD).

Fourth, the U.S. Trade Representative has declared that subsidies on large civil aircraft, which were provided by the European Union (EU), are inconsistent with international trade agreements injuring the U.S. aircraft industry (Office of the United States Trade Representative, 2019). Against this background and under the notion of Trump's 'America first' policies, the U.S. government has renegotiated major trade arrangements (e.g., the North American Free Trade Agreement) and has imposed and threatened multiple rounds of tariffs against important trading partners.

As a backlash to the increasing tendency towards U.S. protectionist policies, several affected countries i.e., China, EU, Canada, Mexico, India, Russia and Turkey responded with tit-for-tat retaliatory actions and imposed tariffs on American products, too. As shown by Figure 2a, the number of new harmful interventions (e.g., tariff measures) implemented by and against the U.S. peaked in 2018 reflecting the worsened global trade tensions. During 2018 and 2019 the trade dispute between the U.S. and China 
escalated most notably and ended up in a trade war with numerous and substantial tariff impositions. As illustrated by Figures $2 \mathrm{~b}$ and $2 \mathrm{c}$, the imposed tariffs are more than six (two and a half) times higher for Chinese (U.S.) exports than before the trade war and cover more than sixty percent of bilateral trade. In this context, the trade dispute between the world's largest economies has become an indispensable subject of economical and political discussions and a major threat to the global economy and the international trading system. Furthermore, the costs of tariff impositions have already been reflected in U.S. business' expectations. Economists, market participants and representatives of companies in the U.S. have become increasingly concerned about the outlook of the international business environment (e.g., fears of a recession, eroding confidence about market access, high input costs, supply chain problems and differed investments) as a result of the elevated trade and political uncertainty (Bloom et al., 2007; Baker et al., 2016; Caldara et al., 2019; Federal Reserve System, 2019). Figure 3a reveals a dramatic rise in trade policy concerns covered by the print media since the intensification of international trade tensions in early 2018.

However and according to the trade policy uncertainty literature, uncertainty about future tariffs does not only affect U.S. companies' expectations and recent economic performance, but also stock market investors' perceptions of U.S. companies' future cash flows (Bianconi et al., 2019). Uncertainty related to the escalating tensions raises the investors' concerns about the economic consequences for affected companies and causes a broad reassessment of risk premia and a revaluation of the company which in turn affects a firm's stock returns (Bianconi et al., 2019). Accordingly, Figure 3b reflects an increased attention to trade policy concerns but especially illustrates the uncertainty of stock market investors of how to perceive the recent trade dispute. Furthermore, Figure $3 \mathrm{~b}$ indicates that tariff uncertainty has become a leading source of U.S. stock market volatility (Baker et al., 2019), which apparently affects stock market investors' sentiments (Pástor and Veronesi, 2012, 2013). Thus, the impact of tariff announcements on stock market investors' expectations will depend on how investors evaluate the consequences of tariff impositions on affected companies. In this context, U.S. stock market investors' perceptions may be 
impaired by the fact that tariffs can exhibit opposing effects ${ }^{1}$ so that the implications for affected companies are not predictable ex ante. Hence, investors' perceptions will heavily depend on the extent of trade disruption caused by imposed and threatened U.S. tariffs and retaliatory actions of involved countries as well as on new information about potential tariff impositions (e.g., tariff announcements), which shifts investors' expectations about the firms' future profits.

Against this background, the paper at hand assesses how tariff announcements influence stock market investors' perceptions by examining abnormal share price reactions of U.S. firms to a series of recent trade restriction announcements. In this context, we consider all announced U.S. tariffs on imports (all Section 201, 232 and 301 investigations) and retaliatory actions from China, EU, Canada, Mexico, India, Russia and Turkey between January 2018 and August 2019. Overall, we employ a unique sample of 2,849 tariff imposition announcements by and against the U.S. targeting 859 listed U.S. companies. Our analysis initially reveals that investors perceive tariff announcements as a negative event for U.S. firms, which is reflected by negative (cumulative) average abnormal stock returns during a symmetric three-day event window. We suggest that stock market investors expect adverse impacts of tariff impositions, e.g. a decrease in the companies' future cash flows and a fear of retaliation. The negative wealth effects are irrespective of whether the Trump administration announces safeguard tariffs to protect domestic firms or retaliation is declared by foreign countries. These results remain robust under a variety of tests even when (i) employing an alternative market model, (ii) varying the estimation window length, (iii) relaxing single model restrictions and (iv) employing an alternative matching identifier. Moreover, building several subsamples, we find that the negative impact is mostly driven by announcements involving China and due to a considerable heterogeneity across sector, tariff, trade and firm characteristics.

The remainder of the paper is organized as follows. While Section 2 discusses the potential short- and long-term macroeconomic implications of rising protectionism from a theoretical perspective, Section 3 provides an overview of related empirical studies and

\footnotetext{
${ }^{1}$ Section 2 provides a detailed discussion of the ambiguous effects and transmission channels of unilateral and bilateral tariffs on affected companies.
} 
carves out the contribution to the existing literature. Section 4 presents the empirical methodology and Section 5 introduces the data. While Section 6.1 and 6.2 present results from our baseline analyses and robustness checks, Section 6.3 discusses results from a large variety of sensitivity analyses. Finally, Section 7 summarizes and concludes.

\section{Theoretical background}

Stock market investors' perceptions towards tariff announcements rely on expectations and available information. Consequently, as the implications of tariffs are not (fully) predictable for affected U.S. companies ex ante, the overall assessment of tariff announcements by stock market investors may be impaired and depends on the anticipated outcome of a tariff imposition. Taking this into account, this section initially discusses potential short- and long-term macroeconomic implications of tariff impositions for U.S. companies. In this context, we identify and consider different transmission channels through which a tariff imposition may affect U.S. firms' economic activity and thus, may affect U.S. firms' stock returns.

Advocates of protectionist policies theoretically argue that a large country, exhibiting monopsony power in trade, can lower the price of foreign exports by reducing its demand for the imported product as a consequence of unilaterally imposed optimal tariffs (Johnson, 1953; Krugman et al., 2018). Thus, a tariff implemented by a large country will positively affect the Terms of Trade (ToT), which are defined as an average price level of a country's exports over imports ${ }^{2}$ at the expense of trading partners (Bickerdike, 1907; Ossa, 2014). These benefits outweigh the potential costs like distorted production and consumption incentives of a tariff (Krugman et al., 2018). From a firm-level perspective, the increase of domestic prices for imported goods due to a tariff imposition may incentivize consumers to switch to domestic alternatives if imported goods can be easily substituted (elastic demand function). This process finally results in increased domestic production and aggregate domestic consumption with regard to protected sectors

\footnotetext{
${ }^{2}$ An improvement in the ToT means that the domestic market receives more import goods for a given level of exports as compared to before the tariff imposition. Furthermore, ToT externality is enhanced by an appreciation of the domestic currency relative to its trading partner's currency.
} 
(Lechthaler and Mileva, 2018; Gunnella and Quaglietti, 2019). By shifting production and profits from foreign firms to domestic firms, the domestic economic activity along the supply chain ${ }^{3}$ rises, more (unskilled) workers are hired and domestic firms receive higher revenues (higher prices) for producing the protected goods (Krugman, 1987; Opp, 2010; Lechthaler and Mileva, 2018; Flaaen and Pierce, 2019). In addition, one main objective of tariff impositions is the protection of domestic industries from (i) foreign import competition (infant industry argument), (ii) foreign excess production and (iii) the risk of falling below minimum viable scale of production (U.S. Department of Commerce, 2018b; Qiu et al., 2019). Consequently, protected sectors face less competition from foreign firms on the domestic market, exhibit an increase in international competitiveness and can expand further (Flaaen and Pierce, 2019). For a country as a whole, it is argued that the increase in producer surplus ${ }^{4}$ and the additional tariff revenues of the government outweigh the loss in consumer surplus due to higher prices (Krugman et al., 2018). Even under retaliation (bilateral tariff impositions), Johnson (1953) as well as Kennan and Riezman (1988) show that - depending on the countries' demand elasticity functions large countries may benefit also in a trade war scenario.

In contrast, critics of protectionism suggest that any potential benefits of employing protectionist policies are short-term and disputable and come at the expense of numerous long-term drawbacks. According to the price channel of tariffs, increasing import prices, especially for intermediate goods, raise domestic production costs (Fusacchia, 2019). Higher input costs cause firms to cut markups and absorb some of the higher costs by reducing profit margins (Amiti et al., 2019; Caldara et al., 2019). Lower profit margins may result in decreased production and employment levels as certain sectors are no longer profitable (Gunnella and Quaglietti, 2019). Furthermore, tariff-induced

\footnotetext{
${ }^{3}$ Note that tariff impositions may be more beneficial for upstream producers by raising the prices of goods, which in turn negatively affects downstream producers that rely on those goods for production (Huang et al., 2019)

${ }^{4}$ From a theoretical perspective, the impacts of a tariff on prices and producers' surplus may depend on the degree of substitutability and the price elasticity functions of supply and demand in the domestic and global markets. In sectors with an inelastic price elasticity, the consumer price rises sharply, whereas the quantity and the producer prices fall only slightly. In contrast, significant reductions in demand and producer prices are assumed in markets with an elastic price elasticity, however, consumer prices experience only a slight increase.
} 
price increases are partly passed through to consumer prices and thus, lower households' disposable incomes (Amiti et al., 2019; Caldara et al., 2019). As a consequence, domestic consumers and companies that heavily depend on charged imports suffer most. In this context, the tariff adversely affects consumption, investment decisions and lowers quantities of international traded goods (quantity channel), which also affects exporters (Caldara et al., 2019). Exporters are struggling with a reduction in foreign demand (Bouët and Laborde, 2018) and an appreciation of the domestic currency (exchange rate channel). Hence, selling products abroad becomes more difficult due to a weakened export competitiveness (tariff raises input costs relative to those of foreign competitors) and thus, may provoke less export quantities and foreign revenues for exporters (Handley and Limão, 2017; Fajgelbaum et al., 2019; Lindé and Pescatori, 2019). This effect would also result in lowered output (quantity channel) and income levels, a decreased demand for productive factors and reduced incentives to invest (Bouët and Laborde, 2018; Amiti et al., 2019; Gunnella and Quaglietti, 2019). Closely related and with regard to the competition channel, tariff impositions may weaken domestic producers' competitiveness in international markets as less open markets restrict access to the most efficient inputs, diminish global competition and reduce incentives for technology upgrades and innovation (Cattaneo et al., 2013; Bouët and Laborde, 2018; Gunnella and Quaglietti, 2019). The participation in global production networks is adversely affected by disrupting global supply chains, shortening global supply linkages and reducing sales along the supply chain (Fajgelbaum et al., 2019; Huang et al., 2019). In addition, the realignment of supply chains is costly and takes time.

With regard to retaliation, critics of protectionism argue that all alleged benefits of a strategic trade policy (e.g., increased ToT, industry protection, higher surplus for producers) are abolished and that conflicting countries will lose in terms of production efficiency and costs, bilateral trade flow, foreign direct investments, competitiveness and consumption (Ossa, 2014; Balistreri et al., 2018; Krugman et al., 2018; Amiti et al., 2019; Fajgelbaum et al., 2019). Overall, a tariff-induced distortion of an optimal resource 
allocation reduces the overall trading volume and restricts future growth and quantities, especially in a trade war scenario (Bouët and Laborde, 2018).

\section{Empirical evidence and contribution}

Empirical studies evaluating the outcomes of recent tariff impositions demonstrate more adverse effects on the U.S. economy. To begin with, higher prices of intermediate and final goods are observed in protected industries (Charbonneau and Landry, 2018; Amiti et al., 2019; Fajgelbaum et al., 2019; Flaaen and Pierce, 2019). Furthermore, it is shown that higher prices may provoke a huge drop in exports and imports for U.S. multinationals and lower productivity (Charbonneau and Landry, 2018; Amiti et al., 2019; Fajgelbaum et al., 2019; International Monetary Fund, 2019). This adversely affects real remunerations (Bouët and Laborde, 2018) and the level of employment (Flaaen and Pierce, 2019). Especially export-orientated companies clearly underperform (Charbonneau and Landry, 2018; Gunnella and Quaglietti, 2019). In addition, it is found that domestic firms may reassess their capital plans by writing off and declining foreign investments (Amiti et al., 2019; Gunnella and Quaglietti, 2019; International Monetary Fund, 2019). Finally, market turmoil may raise, while business and confidence indicators decline and no improvement of ToT can be identified as tariff revenues are insufficient to compensate the losses (Amiti et al., 2019; Gunnella and Quaglietti, 2019; International Monetary Fund, 2019).

While there is a growing strand of empirical literature that evaluates the outcomes of recent tariff impositions, studies that empirically analyze likely changes in U.S. stock market investors' perceptions due to trade policy affairs by means of abnormal stock returns are rather scarce. To begin with, Bianconi et al. (2019) analyze 'Permanent Normal Trade Relations' (PNTR)-related policy announcements and show that stock market investors underestimate the impact of trade liberalization through PNTR by penalizing industries, which were more exposed to trade policy uncertainty prior to the agreement and would benefit most. In contrast, Crowley et al. (2019) document that announcements of trade policy restrictions by the EU are associated with negative 
abnormal returns for Chinese solar panel producers. Finally, analyzing the impact of the election of Donald J. Trump as President of the U.S. on domestic firms' share prices, Wagner et al. (2018) provide ambiguous empirical results. While domestic-orientated firms exhibit positive abnormal stock returns, negative wealth effects are reported for U.S. multinationals due to anticipated protectionist policies.

Most related to our study, Huang et al. (2019) analyze the impact of trade policy shocks (measured by four tariff announcements) on U.S. and Chinese firms' abnormal stock market performance during the recent trade dispute. The authors observe negative abnormal share price reactions for listed U.S. and Chinese firms, especially for international-orientated firms. Also closely related, Egger and Zhu (2019) investigate abnormal share price reactions to tariff announcements and impositions with regard to the U.S.-China trade war. Analyzing 31,217 companies from 40 countries and 19 event dates, the authors find negative (cumulative) abnormal returns in most cases. However and in contrast to Huang et al. (2019), they observe that several U.S. sectors are also positively affected by China's retaliation actions.

From our point of view, the existing empirical studies suffer from the following limitations. First, while Egger and Zhu (2019) and Huang et al. (2019) do not control for the significance of their (cumulative) abnormal returns and for volatility clustering and conditional heteroskedasticity in their time series of stock returns, we employ the nonparametric generalized rank t-statistic as proposed by Kolari and Pynnonen (2011) and a GARCH $(1,1)$ model in order to address these issues. Second, both studies do not control for fundamental and tariff-related confounding events, which may heavily bias the results. We tackle this issue by controlling for merger and acquisition transactions, dividend payments, tariff-increase announcements, tariff imposition dates and tariff-related list announcements. In addition, we omit overlapping and intersecting tariff announcements in order to disentangle the impact of announced tariffs administered by the (i) U.S. government and (ii) foreign countries. Finally, as Egger and Zhu (2019) and Huang et al. (2019) solely focus on specific events with regard to the U.S.-China trade war, we extend the scope of analysis by considering all announced U.S. tariffs on imports (all 
Section 201, 232 and 301 investigations) and retaliatory actions from China, EU, Canada, Mexico, India, Russia and Turkey from January 2018 to August 2019.

\section{Empirical methodology}

Following Brown and Warner (1985), we employ a standard event study methodology in order to analyze the impact of tariff imposition announcements by and against the U.S. on changes in U.S. stock market investors' perceptions. Assuming that stock markets are efficient in a semi-strong form (Fama, 1970), share prices will fully reflect changes in stock market investors' perceptions regarding new information from tariff announcements. Accordingly, we investigate if and how a particular tariff announcement may provoke abnormal share price reactions of listed U.S. firms for the time period from January 2018 to August 2019. In a first step, we calculate the realized excess stock returns $\left(R_{i, t}^{e}\right)$, with respect to the risk-free rate $\left(R_{f, t}\right)$, for each firm $i$ and time $t$ as

$$
R_{i, t}^{e}=\ln \left(\frac{P_{i, t}}{P_{i, t-1}}\right)-R_{f, t}
$$

where $P_{i, t}$ denotes the share price at time t. Subsequently, we fit the time series of $R_{i, t}^{e}$ with a $\operatorname{GARCH}(1,1)$ model to account for time varying volatility clustering and autoregressive conditional heteroskedasticity. Second, we employ the Fama-French three-factor asset pricing model (Fama and French, 1993) to predict the expected stock returns $E\left[R_{i, t}\right]$ for each firm $i$ and time $t$. The Fama-French three-factor model extends the capital asset pricing model by adding (i) a size premium resulting from the outperformance of small caps relative to large caps (SMB) and (ii) a value premium resulting from the outperformance of high book-to-market companies relative to low book-to-market firms (HML) to the overall market factor $\left(R_{m, t}-R_{f, t}\right)$, which is proxied by the excess returns of the Russell 3000 index over the risk-free rate $^{5}$ in our study. We regress each firm's realized excess stock return $R_{i, t}^{e}$ on all three factors during an estimation window starting

\footnotetext{
${ }^{5} R_{m, t}$ represents daily log returns of the Russell 3000 index. The $R_{m, t}-R_{f, t}$ time series are also fitted with a $\operatorname{GARCH}(1,1)$ model.
} 
at $t_{-3}$ and ending at $t_{-2}$, where $t_{-3}<t_{-2}$ is fulfilled. Employing ordinary least squares regression techniques, the expected stock returns $E\left[R_{i, t}\right]$ are calculated as

$$
E\left[R_{i, t}\right]=\alpha_{i}+\beta_{i}\left(R_{m, t}-R_{f, t}\right)+\gamma_{i} S M B_{m, t}+\delta_{i} H M L_{m, t}
$$

where parameters $\alpha_{i}, \beta_{i}, \gamma_{i}$ and $\delta_{i}$ are the regression coefficients to be estimated.

Third, following MacKinlay (1997), we define abnormal stock returns $A R_{i, t}$ for each firm $i$ and time $t$ at and around the respective event dates as the difference between realized excess stock returns $\left(R_{i, t}^{e}\right)$ and model-expected stock returns $E\left[R_{i, t}\right]$ in the absence of the event for any given day in the event window. Defining $t_{0}$ as the date of the event, we set the event window length from $t_{-1}$ as starting point to $t_{1}$ as the end of the event window under the conditions that $t_{-1} \leq t_{0} \leq t_{1}$ and $t_{-3}<t_{-2}<t_{-1}$ hold. Accordingly, abnormal stock returns are estimated as follows

$$
A R_{i, t}=R_{i, t}^{e}-E\left[R_{i, t}\right]
$$

Fourth, the cumulative abnormal stock returns $C A R_{i,\left[t_{-1}, t_{1}\right]}$ for each firm $i$ during the event window $\left[t_{-1}, t_{1}\right]$ are calculated for a single event as

$$
C A R_{i,\left[t_{-1}, t_{1}\right]}=\sum_{t=t_{-1}}^{t_{1}} A R_{i, t} .
$$

In order to analyze observations across firms, we define average abnormal returns $A A R_{t}$ of all firms $N$ at time $t$ and cumulative average abnormal returns $C A A R_{\left[t_{-1}, t_{1}\right]}$ during the event window $\left[t_{-1}, t_{1}\right]$ reporting the mean values of identical events as

$$
\begin{aligned}
A A R_{t} & =\frac{1}{N} \sum_{i=1}^{N} A R_{i, t}, \\
C A A R_{\left[t_{-1}, t_{1}\right]} & =\sum_{t=t_{-1}}^{t_{1}} A A R_{t} .
\end{aligned}
$$


In line with Armitage (1995), we implement a standard estimation window $[-251,-2]^{6}$ for our baseline analysis, which starts 250 trading days prior to the day before the event window starts. The length of 250 trading days ensures a greater precision of regression coefficient estimates as compared to shorter estimation windows. Furthermore, we set the event window to $[-1,1]$ in order to capture short-term share price reactions with regard to tariff announcements and to exclude confounding events ${ }^{7}$, which may bias the results of our event study analysis.

Finally, we employ the non-parametric generalized rank t-statistic ${ }^{8}$ (GRANK-T) as proposed by Kolari and Pynnonen (2011). Kolari and Pynnonen (2011) show that the GRANK-T test offers several advantages over the popular parametric (ordinary t-test, Patell (1976) t-test, and Boehmer et al. (1991) t-test) or non-parametric (Corrado and Zivney (1992) for single day and Cowan (1992) as well as Campbell and Wesley (1993) for multi-day rank tests) procedures. First, the empirical power of the GRANK-T test dominates parametric tests in event study analyses for all event window lengths when assuming that stock prices are not normally distributed due to the absence of a distribution assumption. Second, the proposed test allows for an efficient testing for both single day and cumulative abnormal returns by extending the single day non-parametric test of Corrado and Zivney (1992) and outperforming existing cumulated ranks tests. In addition, the GRANK-T test is robust against abnormal stock return serial correlation, event-induced volatility and a certain degree of cross-sectional correlation caused by event day clustering (Kolari and Pynnonen, 2011).

\section{Data and sources}

We collect data on several rounds of tariff imposition announcements by and against the U.S. between January 2018 and August 2019 from USTR, the Chinese Ministry of Commerce, the Ministry of Industry and Trade of the Russian Federation, the World

\footnotetext{
${ }^{6}$ In order to verify our results, we control for the robustness of our model assumptions by changing the estimation window length to 100 and 400 days in Section 6.2.

${ }^{7}$ The detailed examination of various confounding events is described in Section 5.

${ }^{8}$ For a detailed description of the GRANK-T test procedure see Kolari and Pynnonen (2011).
} 
Trade Organization (WTO), the European Commission and from Bown and Kolb (2019). We set the event date ${ }^{9}$ as the day when a detailed tariff code list with individual product descriptions was published. ${ }^{10}$ We consider U.S. government tariff imposition announcements on imports with regard to Section 201, 232 and 301 investigations and the large civil aircraft dispute with the EU. Moreover, retaliatory announcements on U.S. exports from China, EU, Canada, Mexico, India, Russia and Turkey are included. ${ }^{11}$ In general, tariffs on imports of selected products were released in the format of regionspecific product classification codes. With regard to our sample countries, the tariff list announcements were published in three different code systems, e.g., the Harmonized Commodity Description and Coding System (HS) developed by the World Customs Organization, the Harmonized Tariff Schedule (HTS) administered by USTR and the Combined Nomenclature (CN) operated by the EU. ${ }^{12}$

We initially match international tariff codes with the six-digit North American Industry Classification System (NAICS) codes, which are employed by the U.S. to classify U.S. companies' business activity and U.S. firm-level data. In this context, several process steps and adjustments are necessary. First, we harmonize the different tariff systems and convert them into eight-digit U.S. HTS codes as our standard classification format. Table 1 reports the number of announced U.S. and foreign tariffs for each HTS section. In a second step and based on the study of Pierce and Schott (2012), we employ annual interactive

\footnotetext{
${ }^{9}$ Each announcement was transformed into a U.S. calendar date with regard to Eastern Standard Time (EST). If a tariff announcement was made on a weekend, public holiday or after 4pm EST (closing of New York Stock Exchange), the event was postponed to the next trading day.

${ }^{10}$ The explicit tariff codes are necessary to match international trade and tariff data to granular productlevel data of U.S. companies. In this context, we exclude Japan from our sample because Japan's announcement of retaliatory tariffs, which were a response to import adjustment measures imposed by the U.S. on 18 May 2018, does not provide specific information on the scope of underlying products.

${ }^{11}$ In order to ensure the completeness of our sample, we consider initial product list and revised list announcements. On the product-level, we exclude revised list announcements if the specific product group was already announced in a prior list (initial list or previous revised lists). In this context, the event date is set according to the first announcement.

${ }^{12}$ The HS was introduced in 1988 and has been contracted by 158 (July 2019) countries worldwide. The underlying HS codes consist of six digits organized in a hierarchical structure (chapter, headings and subheadings). The hierarchical structure was introduced to classify the commodity groups in a more disaggregated way. Building on this six-digit code, the HS code is often extended for regional purposes. As regards the HTS codes, the U.S. International Trade Commission releases eight- and ten-digit codes. The first six digits determine the HS code, the next two digits identify U.S. subheadings and established tariff rates and the last two digits are provided for statistical purposes (statistical suffix). With respect to eight-digit $\mathrm{CN}$ codes administered by the EU, the first six digits also represent the HS code and the last two digits introduce further EU subdivisions.
} 
concordances of the U.S. Census Bureau (USCB) for imports and exports to link HTS codes and NAICS product classes. As a result, we are able to analyze matched tariff and production data at a more disaggregated level. Third, unmatched HS and CN codes as well as unclassified HTS codes are hand-matched by means of published product descriptions, if possible. Finally, we employ NAICS codes as a firm-level matching identifier. We search the entire Center for Research in Security Prices (CRSP) and Compustat - Capital IQ databases for listed companies, which have concordant primary NAICS codes, and which are headquartered (Current ISO Country Code - Headquarters) and incorporated (Foreign Incorporation Code) in the U.S. As a result, daily stock prices and fundamental balance sheet data for identified U.S. companies are retrieved from these databases. Next to these tariff and firm-level data, further complementary data is necessary for our analysis. While Fama-French factors as well as the risk-free rate are collected from Kenneth French's data library, we obtain Russell 3000 data from Refinitiv's Datastream. Finally, firm-level and country-level trade data are retrieved from the USCB and Hoberg-Moon Offshoring Repository database (Hoberg and Moon, 2017, 2019).

When performing an event study analysis it is imperative to control for confounding events, which may bias estimation results. We define several criteria for the exclusion of confounding events. To begin with, in order to separate the impact of tariff announcements administered by the U.S. government and foreign countries on U.S. firms' share prices, we consider tariff-related confounding events and omit all overlapping and intersecting tariff data (i.e., announcements, tariff increases, effective dates of imposed tariffs) with regard to primary NAICS codes during the event window. Next, we control for two well-known general types of confounding events, which have been identified in the context of event study methodologies based on share price information (Bowman, 1983). Accordingly, we exclude all firms exhibiting announcement or effective dates of merger and acquisition (M\&A) transactions (e.g., Malatesta, 1983; Doukas and Travlos, 1988; Goergen and Renneboog, 2004) and dividend payment dates (e.g., Asquith and Mullins Jr, 1983) during the event window. ${ }^{13}$ In addition, we drop firms, which are mainly traded on undetermined

\footnotetext{
${ }^{13}$ Firm-level M\&A data is obtained from Refinitiv's Eikon. Data on a firm's dividend payments are retrieved from CRSP and Compustat - Capital IQ.
} 
over-the-counter exchanges (Compustat - Capital IQ: Stock Exchange Code) due to insufficient data quality. Moreover, we exclude companies with (i) missing share price data during estimation or event windows, (ii) missing trading activities for at least five consecutive trading days during the estimation window and (iii) shares, which are worth less than a dollar (pennystocks) during estimation or event windows. Both, the exclusion of missing data and pennystocks are implemented in order to ensure sufficient liquidity of the identified firms' shares. Finally, we do not include companies with positive or negative daily stock price returns of more than $+/-25 \%$ (daily return boundary) in order to avoid non-observable confounding events, which may bias the results of our event study analysis. ${ }^{14}$

Overall, our final sample consists of 2,849 tariff announcement events targeting 859 listed U.S. companies. ${ }^{15}$ While Table 2 reports the descriptive statistics of tariff, trade and firm characteristics for the identified 2,849 tariff announcements in our sample, the respective variables are described in Table 3. As shown by Table 2, the average government-announced tariff rate on specific types of goods and services is about 15.5\%. Moreover, the announced tariff rates are quite heterogeneous and range between $5 \%$ and $50 \%$. In addition, $23 \%$ of identified tariff announcements affect a specific NAICS classification code for the first time. The remaining $77 \%$ represent follow-up announcements. With regard to respective trade characteristics, we observe that $58 \%$ of all tariff announcements are imposed to product groups, which are exposed to a trade deficit from the U.S. perspective. Furthermore, the fraction of multinational firms selling goods to $(57 \%)$ or purchasing goods from China (55\%) is slightly higher as compared to domestic-acting firms in our sample while the average firm is a large firm with $\$ 13.2$ billion of market capitalization and with earnings per share in the amount at $\$ 2.55$. Finally, approximately $55 \%$ of the firms targeted by recent tariff announcements exhibit an investment-grade rating.

\footnotetext{
${ }^{14}$ We relax several restrictions during the robustness checks in Section 6.2.

${ }^{15}$ Relaxing several restrictions during later analyses, our sample increases to 4,111 events involving 1,196 listed U.S. firms.
} 


\section{Empirical Results}

Results from our baseline analyses are presented in Tables 4 - 17 and Figures 4 - 17. While results from model-robustness checks are provided in Table 18, sensitivity analyses from investigating different subsamples are reported in Tables 19 - 22.

\subsection{Baseline analyses}

In this subsection, we investigate how recent tariff announcements influence U.S. stock market investors' perceptions. In a first step, we split our entire sample with regard to the respective originator of tariff announcements in order to disentangle the potential effects on U.S. firms from different tariff announcement intentions (U.S. safeguard tariffs vs. foreign retaliatory actions). Subsequently, we shed a brighter light on the escalating trade tensions with China by analyzing the successive rounds of tariff announcements, respectively.

\subsubsection{U.S. safeguard tariffs vs. foreign retaliatory actions}

As shown by Tables 4 and 5, independent from the originator and intention of the tariff, we provide evidence for a negative and significant average abnormal stock return (AAR) at the announcement date. This finding is in line with previous empirical findings provided by Egger and Zhu (2019) and Huang et al. (2019). Our results suggest that the announcement of tariffs is weighing on U.S. stock market investor's perceptions (Pástor and Veronesi, 2012, 2013) by potentially eroding confidence, raising concerns about the economic consequences for affected companies and reflecting fears of retaliatory tariffs and

escalating tensions. Stock market investors may expect a decrease in U.S. firms' value, which may result from the negative effects of tariff, such as higher input costs, lower profit margins, declined trading volumes, disrupted supply chains and less competitiveness (Bouët and Laborde, 2018; Amiti et al., 2019; Fajgelbaum et al., 2019; Gunnella and Quaglietti, 2019).

While the GRANK-T test demonstrates that AARs are significantly negative for both U.S. (-0.44\%) and foreign announcements (-0.68\%) at the event day, we additionally 
observe a significantly negative AAR (-0.40\%) for U.S. announcements on the post-event day. These findings indicate that the impact of tariff announcements is not immediately and completely perceived by stock market investors. As investors' expectations take more than one day to adjust to new information on tariffs announced by the U.S. administration, we suggest that this might be due to the fact that the initial actions of each analyzed trade dispute were always triggered by the U.S., so that expectations of a subsequent retaliation will be priced in more quickly. As indicated by the significantly low proportions (35\% and $33 \%$ ) of U.S. firms exhibiting positive AARs at the event date, we rule out that our results are biased by a few outliers.

Turning to cumulative average abnormal stock returns (CAARs), we find significantly negative CAARs and a proportion of positive CAARs, which is significantly lower than $50 \%$ for both subsamples and all event window variations (Tables 4 and 5). Figures 4 and 5 illustrate the development of CAARs during our main event window $[-1,1]{ }^{16}$ With regard to announced U.S. tariffs, CAARs from stocks issued by U.S. companies reveal a continuously downward sloping trend. However, CAARs induced by foreign announcements drop only on the day of the event.

Overall, the negative impact of foreign tariff announcements on U.S. stock market investors' perceptions was expected since retaliatory actions may harm a company's economic activity. In contrast, however, the likewise negative effect of U.S. safeguard tariffs on U.S. stock market investors' perceptions reveals that investors are uncertain and not convinced of political and economic arguments by the Trump administration proclaiming an improvement of economic conditions and competitiveness for U.S. companies due to tariff impositions (U.S. International Trade Commission, 2017a,b; U.S. Department of Commerce, 2018a,b; Office of the United States Trade Representative, 2018, 2019). Accordingly, our results do not support theoretical predictions (Krugman, 1987; Opp, 2010) and former empirical evidence (Bianconi et al., 2019) suggesting that

\footnotetext{
${ }^{16}$ The main event window was set to $[-1,1]$ for the following reason. The tight definition of the event window significantly reduces the risk of being exposed to observable and unobservable confounding events, which may bias our results. With regard to our analysis, this issue is highly relevant since countermeasures were announced very promptly after U.S. initial actions. Moreover, overlapping events due to an extended event window length would lead to a huge drop of observations.
} 
stock market investors may perceive tariffs as value-creating for affected companies due to increasing revenues ex post for example (Lechthaler and Mileva, 2018; Flaaen and Pierce, 2019). In contrast and in line with empirical studies investigating the macroeconomic impact of the recent trade disputes, we provide evidence for the fact that investors expect worsened economic conditions for U.S. companies due to tariff announcements, which negatively affect U.S. companies' stock returns. The change in investors' perceptions may be due to a threat of retaliation (Wagner et al., 2018), worsened economic prospects (International Monetary Fund, 2019) or a higher level of trade policy uncertainty (Caldara et al., 2019).

\subsubsection{U.S. - China trade war}

In this subsection, we initially control if especially tariff announcements from China drive our results since trade tensions between the U.S. and China have dominated economic and political debates and have led to substantial reactions on financial markets. Against this background, we analyze whether the involvement of China in a tariff announcement influences U.S. stock market investors' perceptions rather than tariff announcements by other countries in our sample (EU, Canada, Mexico, India, Russia and Turkey). Accordingly, we split our entire sample of tariff announcements into four groups: (i) U.S. against non-Chinese countries (Table 6), (ii) non-Chinese countries against U.S. (Table 7), (iii) U.S. against China (Table 8) and (iv) China against U.S. (Table 9). Figures 6-9 present the development of CAARs during main event window [-1,1] for each group, respectively.

As shown by Tables 6-9, while results from Section 6.1.1 are confirmed for tariff announcements involving China only, we do not provide any statistical evidence for threatened U.S. tariffs against or retaliatory actions from non-Chinese countries. We suggest that the volumes (U.S.-China: approx. $\$ 788$ billions, U.S.-non-Chinese countries: approx. $\$ 95$ billions) and the quantities (U.S.-China: over 20k products, U.S.-non-Chinese countries: under $2 \mathrm{k}$ products) of announced tariffs have a significant impact on investors' perceptions. In this context, the reliance of U.S. firms on Chinese markets in terms of 
imports and exports and the strong integration of Chinese firms into the supply chains of U.S. multinationals (Egger and Zhu, 2019; Huang et al., 2019) weigh more on stock market investors' sentiment as compared to the trade relations with other nations.

Since we identify the relationship between China and the U.S. as a major source of analyzed negative (C)AARs, we will focus exclusively on the trade dispute between both countries in the following. The trade war has seen the U.S. and China announcing different tariffs and retaliatory actions. Especially, the so-called 'List 1 - List 4' announcements of the Trump administration and the related 'List 1 - List 4' retaliations of the Chinese government have been the key events during the trade war. Taking this into account, we split our sample into the four individual rounds of tariff announcements between both countries in order to analyze the escalating trade tensions between the U.S. and China at a more disaggregated level.

As shown by Tables 10-17 and Figures 10-17, results from our aggregated main analysis are generally reiterated. Except for Chinese rounds 1 and 4, we provide evidence for negative and statistical significant AARs at the announcement date and a significant decrease of CAARs during the $[-1,1]$ event window. ${ }^{17}$ When comparing the magnitude of the impact of U.S. safeguard tariff and Chinese retaliation announcements on U.S. stock market investors' perceptions in each round, we find that nearly all AARs, which are triggered by Chinese announcements, exhibit more negative values at the respective event dates. However, when comparing CAARs induced by U.S. and Chinese tariff announcements in each tariff round, we observe a harmonization in the magnitude of CAARs during the respective main event windows $[-1,1]$, except for round 1 . In other words, our analysis reveals that both, U.S. safeguard tariff and Chinese retaliatory action announcements, provoke a similar negative change in investors' perceptions during the event window. Hence, our findings suggest that retaliation is not (fully) priced in by U.S. stock market investors after U.S. tariff announcements. Nevertheless, we mainly observe a decreasing, but still significant, impact of announced tariffs throughout the chronological

\footnotetext{
${ }^{17}$ Note however that results from Chinese tariff rounds 1 and 4 must be taken with caution since the number of observations is small. The small numbers are mainly due to overlapping announcements of tariffs on similar product groups by and against the U.S. with regard to each specific primary NAICS code (tit-for-tat announcements) during the event window. These confounding events are omitted.
} 
sequence of respective tariff rounds, which is indicated by declining absolute values of CAARs within the main event window $[-1,1]$. This result demonstrates that investors seem to adjust, to a certain extent, their perceptions towards tariff announcements during the trade war, which might be due to an anticipation of these events over time.

\subsection{Robustness checks}

In this subsection, we perform various robustness checks by relaxing several restrictions from our baseline analyses. The results from analyzing the aggregated U.S. and Chinese rounds of tariff announcements (Tables 8 and Table 9) are defined as baseline results and will serve as a benchmark for the following robustness tests. By implementing a difference in means t-test, we check for significant differences between CAARs within in the $[-1,1]$ event window. This test suggests unequal variances if the test of equal variances is rejected at the $5 \%$ level. Results from respective robustness checks are reported in Table 18.

First, we control for the specification of our market model. Accordingly, we substitute the Fama-French three-factor model (Fama and French, 1993) by Carhart's four-factor model. Carhart (1997) extends the approach of Fama-French by a momentum factor ${ }^{18}$ for the asset pricing of stocks. As shown by Table 18, we do not observe a significant difference between the factor models for both subsamples. Therefore, we rule out that our results are biased due to the specification of the market model.

Second, the choice of the estimation window length involves several tradeoffs and may affect the results (Armitage, 1995). Even though longer estimation periods are more precisely and smooth the prediction of stock returns, the estimated coefficients become more 'out of date'. In contrast, shorter windows put more emphasis on current economic developments, but they are more prone to outliers affecting the quality of stock return predictions. As it is suggested that estimation periods of 100 days or more are accurate for event studies, we address this issue by implementing two different lengths (100 days and 400 days) for the prediction of abnormal stock returns. As reported by Table 18,

\footnotetext{
${ }^{18}$ The momentum factor describes the tendency of stocks to maintain recent price trends in the near term, e.g., the tendency of winning (losing) stocks to continue performing well (poorly) in the future (Carhart, 1997).
} 
differences for both estimation window lengths and subsamples turn out to be insignificant indicating that our results are robust even when employing shorter and longer estimation periods.

Third, the implemented return boundary exclude U.S. companies with extremely high daily returns, which may indicate non-observable confounding events that may bias our baseline estimations. In the following, we relax the daily return boundary in order to control whether the implementation was too restrictive. Accordingly, we allow for a doubling of this boundary and consider U.S. companies with positive or negative daily stock returns of less than or equal to $+/-50 \%$. As shown by Table 18 , our results are qualitatively reiterated for both samples even when relaxing the boundary constraint.

Fourth, even though the exclusion of those shares being worth less than a dollar is reasonable since pennystocks are characterized by lower trading frequencies, higher volatility levels and insufficient liquidity, we allow for the inclusion of pennystocks in a next robustness check. However as reported by Table 18, differences for both samples turn out to be insignificant demonstrating that our results are robust even when including pennystocks.

Fifth and finally, since the identification whether a U.S. company is targeted by a tariff announcement depends on the employed classification system for product groups and companies business activities, we control for the selection of primary NAICS as our matching identifier. Accordingly, we substitute the six-digit NAICS code by the fourdigit Standard Industrial Classification (SIC) system, which is widely used in the U.S. In this context, interactive concordances and NAICS-to-SIC-crosswalks of the USCB are employed in order to transfer NAICS codes into SIC codes. ${ }^{19}$ As shown by Table 18, however, we do not observe a significant difference in results when employing primary NAICS or SIC codes as matching identifiers.

\footnotetext{
${ }^{19}$ All process steps as described in Section 5 are repeated with primary SICs as an alternative matching identifier.
} 


\subsection{Sensitivity analyses}

In order to gain a deeper understanding of the impact of tariff imposition announcements on U.S. stock market investors' perceptions, we perform a variety of sensitivity analyses focusing on sector, tariff, trade and firm characteristics. The description of the variables are given by Table 3. Respective empirical results are reported in Tables 19-22.

\subsubsection{Sector analysis}

To begin with, we control if the change of U.S. stock market investors' perceptions towards tariff announcements depends on the industry sector under investigation. Accordingly, we split the entire sample into different business sectors employing the Global Industry Classification Standard (GICS) developed by MSCI and Standard \& Poor's. ${ }^{20}$ Companies are classified into eleven industry sectors following their principal business activity, which is determined by quantitative (e.g., revenues) and qualitative (e.g., market perceptions) factors. We exclude four specific GICS sectors (financials, communication services, utilities and real estate) due to data-availability reasons. Moreover, these sectors have hardly been affected during the recent trade disputes.

As reported by Table 19, we observe negative and significant CAARs only for the health care, industrials, information technology and materials sectors, whereas no statistical evidence is found for the energy and both consumer sectors. Our findings are irrespective of whether the Trump administration announces safeguard tariffs against China or retaliation is declared by the Chinese government. We suggest that in particular high-technology sectors (e.g., health care and information technology) are at the heart of U.S.-China tensions, especially from a political perspective (see Section 1). Moreover, these sectors may suffer most from trade restrictions due to their organizational structure. This is due to the fact that threatened and imposed tariffs exacerbate crossborder investments, the access to highly specialized inputs, the collaboration in highly technologized fields (e.g., artificial intelligence, cancer research) and disrupt supply chains

\footnotetext{
${ }^{20}$ GICS codes are retrieved from Compustat - Capital IQ.
} 
that helped to create innovation. In addition, tariff impositions may reduce Chinese companies' dependence on highly specialized U.S. inputs and thus, may reduce U.S. companies foreign sales. As regards industrials and materials, these sectors are heavily exposed to a large number of tariff announcements (see Table 1$)^{21}$ and thus, may affect U.S. stock markets investors' perceptions negatively.

\subsubsection{Tariff characteristics}

We proceed and employ subsamples with regard to different tariff characteristics in order to investigate, if and to what extent these characteristics may change U.S. stock market investors' expectations. Respective results from this sensitivity analyses are reported in Table 20 .

Tariff rate To begin with, we analyze different levels of tariff rates since investors may associate higher tariff rates with higher domestic production costs, a greater extent of trade barriers limiting the quantity of international traded goods and more disrupted supply chains. If this is true, investors may perceive higher tariff rates more negatively which results in stronger negative CAARs.

As shown by Panel A in Table 20, we initially find negative and statistically significant CAARs for all subsamples. However, as we additionally observe stronger negative CAARs for tariff rates above 10\% (as indicated by significant differences), our findings support the view that higher tariff rates may trigger the negative perceptions.

Tariff announcement vs. tariff increase We further investigate if and to what extent U.S. stock market investors perceive an adjustment of tariffs (tariff increase) on a subsequent date. Accordingly, we employ further data on announced tariff increases and identify 822 of such events targeting 756 U.S. companies.

As reported by Panel B in Table 20, we do not find that tariff increase announcements produce significant CAARs while the differences between initial tariff list and tariff

\footnotetext{
${ }^{21}$ Note that both consumer sectors are underrepresented in our sample (cf. Table 1). This is due to several tariff-induced confounding events (tit-for-tat exclusions) and may explain the insignificant results for these sectors.
} 
increase announcements are statistically significant irrespective of the originator. Taking this into account, we suggest that tariff increases may be already anticipated when initial tariff lists were announced.

First announcement of a classification code Finally and related to the former analysis, we investigate if the chronological sequence of tariff announcements may have a decisive impact on investors' information processing. We argue that the first time announcement of a tariff should be more surprising and may include more relevant information for investors than a subsequent announcement. If this is true, we suggest that first time announced tariffs may have a greater impact on investors' perceptions than following announcements.

Panel $\mathrm{C}$ in Table 20 reveals significantly negative CAARs for both first-time and follow-up announcements while investors perceive first-time tariff announcements as more harmful. However, the difference between respective CAAR values is only significant for announcements administered by the Chinese government. Corresponding to findings from Section 6.1.2, results from this sensitivity analysis again demonstrate that the negative impact of subsequent tariff announcements is still significant, but declines over time.

\subsubsection{Trade characteristics}

In this subsection we investigate whether different characteristics of the trade relationship between the U.S. and China may change U.S. stock market investors' perceptions towards tariff announcements. Respective results from these sensitivity analyses are reported in Table 21.

U.S. trade balance During Trump's election campaign, trade deficits were blamed for representing an existential threat to U.S. jobs and national security. Accordingly, the U.S. trade deficit with China was one of Trump's main reasons for proclaiming U.S. protectionist policies. Against this background, we control whether a specific product group (NAICS) was subject to a bilateral trade deficit or trade surplus from the U.S. perspective. This fact may be perceived differently by U.S. stock market investors. 
As shown by Panel A in Table 21, we initially observe negative CAARs for all subsamples independently from the underlying trade balance account with China. Furthermore, considerably higher abnormal share price reactions are reported under a framework of a trade surplus, respectively. However, we only observe a significant difference for tariffs which are announced by the U.S. government. Our results indicate that U.S. stock market investors more negatively perceive announcements of tariffs against products exhibiting a trade surplus. We suggest that these tariffs may have been surprising and thus, were less anticipated by U.S. stock market investors since these product groups were not part of prior political and public debates about protectionist policies in the sense of reducing trade deficits during Trump's election campaign.

Imports from and exports to China Investors' expectations towards the impact of tariff announcements on U.S. firms may also be driven by the issue, if companies act cross-border and especially if they trade with Chinese firms. As companies, which are more dependent on the U.S.-China bilateral trade flows, should be more prone to a greater extent of trade restrictions and the escalating tensions between both countries, we suggest that tariff announcements may affect multinational operating U.S. companies more heavily. In order to identify U.S. companies that do business with Chinese firms, we collect data on imports from and exports to China by U.S. companies in our sample. Respective data is retrieved from the Hoberg-Moon Offshoring Repository database (Hoberg and Moon, 2017, 2019).

As shown by Panels $\mathrm{B}$ and $\mathrm{C}$ in Table 21, we find higher negative CAAR values for multinational firms importing from and exporting to China. Moreover, differences between the respective subsamples are statistically significant in most cases. Our results are in line with theoretical predictions from the Melitz model (Melitz, 2003) and empirical evidence provided by Charbonneau and Landry (2018), Amiti et al. (2019), International Monetary Fund (2019) and Huang et al. (2019) suggesting that multinational companies suffer most from an increase in foreign trade restrictions. These companies are more exposed to the threat of retaliatory tariffs, trade policy uncertainty and declines in expected future profits due to higher production costs and a shrinking export market 
(Charbonneau and Landry, 2018; Caldara et al., 2019; Amiti et al., 2019). However, and in contrast to Wagner et al. (2018), Table 21 also reveals significantly negative CAARs for U.S. firms with less international trade relations.

\subsubsection{Firm characteristics}

Finally, we investigate, if and to what extent different firm characteristics may influence U.S. stock market investors' perceptions towards tariff announcements. Respective results are reported in Table 22.

Firm size Companies' business models and revenue structures are determined by their size and the variation of produced goods. Following Gort (1962) and Grossmann (2007), larger companies are associated with a greater and more segmented product diversification potential and thus, are less dependent from earnings from a single product. Accordingly, as tariff impositions are announced on a product-level basis, we analyze whether U.S. stock market investors' perceptions towards tariff announcements depend on the firms' size and their ability to compensate adverse impacts from tariff impositions through alternative business activities.

As shown by Panel A in Table 22, we observe significantly negative CAARs for both, large and small U.S. companies. While CAARs induced by U.S. tariff announcements do not remarkably differ in their values, we only find significantly negative CAARs for smaller U.S. firms as a response to Chinese tariff announcements. We suggest that investors expect a stronger negative impact from Chinese tariffs on smaller U.S. businesses as smaller firms should more heavily suffer from trade restrictions like diminished primary business' earnings, bilateral trade quantities and customers abroad. Moreover, small U.S. businesses may be more adversely affected by disrupted supply chains since it may be more difficult for them to substitute partners along the value chain.

Performance and Rating Following Caballero and Krishnamurthy (2008), unusual or unexpected events may heavily affect investors' behavior and can force them to revaluate their investments, which may temporarily result in 'flight to quality' movements. In this 
context, investors replace more risky and worse-performing securities by safer assets, which exhibit less volatile and more valuable return structures, in order to stabilize portfolio outcomes, especially in times of financial distress. Against this background, as tariff announcements have become a sustainable trigger of the U.S. stock market volatility (Baker et al., 2019) and negatively affect stock market investors' sentiments (Pástor and Veronesi, 2012, 2013), we investigate whether the creditworthiness and current economic performance of U.S. companies may explain variations in U.S. stock market investors' perceptions towards tariff announcements.

As shown by Panels $\mathrm{B}$ and $\mathrm{C}$ in Table 22, we find higher significantly negative CAAR values for worse performing and non-investment grade rated U.S. firms for both subsamples while differences are significant in case of Chinese tariff announcements only. Our results reveal that investors perceive tariffs targeting worse performing and worse rated U.S. companies more negatively which may be due to the fact that tariffs are an impediment especially for these companies.

\section{Summary and conclusion}

Employing 2,849 tariff imposition announcements by and against the U.S. targeting stocks issued by 859 U.S. companies over the period from 2018 to 2019, the study at hand investigates if tariff announcements may induce abnormal share price reactions. Implementing an event study methodology, our analysis initially reveals negative (cumulative) average abnormal stock returns during a symmetric three-day event window due to tariff announcements. Our results are observed independent from the fact if the U.S. government announces safeguard tariffs to protect domestic firms or if foreign countries proclaim retaliatory actions. In addition, we find that the negative perceptions of U.S. stock market investors towards tariff announcements are mostly driven by announcements involving China. While the adverse impacts of Chinese tariff announcements on U.S. stock market investors' perceptions are expected since retaliatory measures may harm a company's economic activity, the negative effect of U.S. safeguard tariffs is rather unexpected and indicates that investors perceive the rising protectionism 
of the Trump administration as a negative event, too. We suggest that U.S. stock market investors' perceive tariffs as harmful for U.S. companies since tariffs may lead to a higher trade policy uncertainty, a threat of retaliatory tariffs and escalating tensions. Furthermore, U.S. stock market investors may expect a decrease in U.S. firms' value and future cash flows as a consequence of the negative impact of tariffs, such as higher input costs, lower profit margins, declined trading volumes, disrupted supply chains and a reduced level of competitiveness (Bouët and Laborde, 2018; Amiti et al., 2019; Fajgelbaum et al., 2019; Gunnella and Quaglietti, 2019).

Our baseline results remain robust under various robustness tests, i.e. (i) employing an alternative market model, (ii) varying the estimation window length, (iii) relaxing single model restrictions and (iv) employing an alternative matching identifier. Performing a large variety of sensitivity analyses produces further important results. To begin with, we find significantly negative CAARs for the high-technology sectors and for companies from the industrial and material sector. Furthermore, we observe that higher tariff rates and first-time tariff announcements of a specific classification code provoke stronger negative CAARs while tariff increase announcements may be already anticipated when initial tariff lists were announced. In addition, the analysis reveals that investors perceive tariff announcements as more harmful under a framework of a trade surplus. Finally, we find that announced tariffs on products from cross-border acting, smaller, worse-performing and non-investment grade U.S. companies are associated with higher negative CAARs.

The study at hand provides an important contribution to the vital debate on short- and long-term economic effects from tariffs by and against the U.S. by measuring CAARs for affected U.S. companies and evaluating the driving factors behind this process. Our results support theoretical and empirical studies which emphasize the negative consequences of the recent trade disputes on the U.S. economy (e.g., Bouët and Laborde, 2018; Charbonneau and Landry, 2018; Amiti et al., 2019; Gunnella and Quaglietti, 2019) and provide important economic implications. First, our results indicate that negative wealth effects from tariff announcements only slowly decrease over the chronological sequence of of respective tariff rounds. Taking this into account, rearising tensions and further tariff 
announcements may be perceived as negative events by U.S. stock market investors as long as the trade disputes are not entirely resolved. Second, the U.S. government should be aware of the fact that U.S. safeguard tariffs, which actually aim at protecting domestic companies, may impede these companies as well, which is especially true for companies operating cross-border or in high-technology sectors. 


\section{References}

Amiti, M., Redding, S. J., and Weinstein, D. (2019). The impact of the 2018 trade war on US prices and welfare. National Bureau of Economic Research Working Paper.

Armitage, S. (1995). Event study methods and evidence on their performance. Journal of Economic Surveys, 9(1):25-52.

Asquith, P. and Mullins Jr, D. W. (1983). The impact of initiating dividend payments on shareholders' wealth. The Journal of Business, 56(1):77-96.

Baker, S. R., Bloom, N., and Davis, S. J. (2016). Measuring economic policy uncertainty. The Quarterly Journal of Economics, 131(4):1593-1636.

Baker, S. R., Bloom, N., Davis, S. J., and Kost, K. J. (2019). Policy News and Stock Market Volatility. NBER Working Paper No. 25720.

Balistreri, E. J., Böhringer, C., and Rutherford, T. (2018). Quantifying disruptive trade policies. CESifo Working Paper No. 7382.

Bianconi, M., Esposito, F., and Sammon, M. (2019). Trade Policy Uncertainty and Stock Returns. Working Paper.

Bickerdike, C. F. (1907). Review of A. C. Pigou. Protective and Preferential Import Duties. The Economic Journal, 17(65):98-102.

Bloom, N., Bond, S., and Van Reenen, J. (2007). Uncertainty and investment dynamics. The Review of Economic Studies, 74(2):391-415.

Boehmer, E., Masumeci, J., and Poulsen, A. B. (1991). Event-study methodology under conditions of event-induced variance. Journal of Financial Economics, 30(2):253-272.

Bouët, A. and Laborde, D. (2018). US trade wars in the twenty-first century with emerging countries: Make America and its partners lose again. The World Economy, 41(9):2276-2319. 
Bowman, R. G. (1983). Understanding and conducting event studies. Journal of Business Finance $\&$ Accounting, 10(4):561-584.

Bown, C. P. and Kolb, M. (2019). Trump's Trade War Timeline: An Up-to-Date Guide. Peterson Institute for International Economics Publications.

Brown, S. J. and Warner, J. B. (1985). Using daily stock returns: The case of event studies. Journal of Financial Economics, 14(1):3-31.

Caballero, R. J. and Krishnamurthy, A. (2008). Collective risk management in a flight to quality episode. The Journal of Finance, 63(5):2195-2230.

Caldara, D., Iacoviello, M., Molligo, P., Prestipino, A., and Raffo, A. (2019). The economic effects of trade policy uncertainty. Journal of Monetary Economics.

Campbell, C. J. and Wesley, C. E. (1993). Measuring security price performance using daily NASDAQ returns. Journal of Financial Economics, 33(1):73-92.

Carhart, M. M. (1997). On persistence in mutual fund performance. The Journal of Finance, 52(1):57-82.

Cattaneo, O., Gereffi, G., Miroudot, S., and Taglioni, D. (2013). Joining, upgrading and being competitive in global value chains: a strategic framework. World Bank Policy Research Working Paper 6406.

Charbonneau, K. B. and Landry, A. (2018). The trade war in numbers. Bank of Canada Staff Working Paper.

Corrado, C. J. and Zivney, T. L. (1992). The specification and power of the sign test in event study hypothesis tests using daily stock returns. Journal of Financial and Quantitative Analysis, 27(3):465-478.

Cowan, A. R. (1992). Nonparametric event study tests. Review of Quantitative Finance and Accounting, 2(4):343-358. 
Crowley, M. A., Meng, N., and Song, H. (2019). Policy shocks and stock market returns: Evidence from Chinese solar panels. Journal of the Japanese and International Economies, 51:148-169.

Davis, S. J., Liu, D., and Sheng, X. S. (2019). Economic Policy Uncertainty in China Since 1949: The View from Mainland Newspapers. Working Paper.

Doukas, J. and Travlos, N. G. (1988). The effect of corporate multinationalism on shareholders' wealth: Evidence from international acquisitions. The Journal of Finance, 43(5):1161-1175.

Egger, P. H. and Zhu, J. (2019). The US-Chinese Trade War: An Event Study of StockMarket Responses. CEPR Discussion Paper No. DP14164.

Executive Office of the President of the United States (2015). The economic benefits of U.S. trade.

Fajgelbaum, P. D., Goldberg, P. K., Kennedy, P. J., and Khandelwal, A. K. (2019). The return to protectionism. National Bureau of Economic Research Working Paper.

Fama, E. F. (1970). Efficient capital markets: A review of theory and empirical work. The Journal of Finance, 25(2):383-417.

Fama, E. F. and French, K. R. (1993). Common risk factors in the returns on stocks and bonds. Journal of Financial Economics, 33(1):3-56.

Federal Reserve System (2019). The Beige Book - November 2019. Federal Reserve System Publication.

Flaaen, A. and Pierce, J. (2019). Disentangling the Effects of the 2018-2019 Tariffs on a GloballyConnected U.S. Manufacturing Sector. Finance and Economics Discussion Series 2019-08, Federal Reserve Board, Washington, D.C.

Fusacchia, I. (2019). Evaluating the Impact of the US-China Trade War on Euro Area Economies: A Tale of Global Value Chains. Italian Economic Journal. Forthcoming. 
Goergen, M. and Renneboog, L. (2004). Shareholder wealth effects of European domestic and cross-border takeover bids. European Financial Management, 10(1):9-45.

Gort, M. (1962). Diversification and integration in American industry. Princeton University Press, Princeton.

Grossmann, V. (2007). Firm size and diversification: Multiproduct firms in asymmetric oligopoly. International Journal of Industrial Organization, 25(1):51-67.

Gunnella, V. and Quaglietti, L. (2019). The economic implications of rising protectionism: a euro area and global perspective. Economic Bulletin, 3:40-62.

Handley, K. and Limão, N. (2017). Policy uncertainty, trade, and welfare: Theory and evidence for China and the United States. American Economic Review, 107(9):27312783.

Hoberg, G. and Moon, S. K. (2017). Offshore activities and financial vs operational hedging. Journal of Financial Economics, 125(2):217-244.

Hoberg, G. and Moon, S. K. (2019). The offshoring return premium. Management Science, 65(6):2876-2899.

Huang, Y., Lin, C., Liu, S., and Tang, H. (2019). Trade Networks and Firm Value: Evidence from the US-China Trade War. CEPR Discussion Paper No. DP14173.

International Monetary Fund (2019). World Economic Outlook, October 2019: Global Manufacturing Downturn, Rising Trade Barriers.

Johnson, H. (1953). Optimum Tariffs and Retaliation. Review of Economic Studies, 21(2):142-153.

Jorion, P., Liu, Z., and Shi, C. (2005). Informational effects of regulation FD: Evidence from rating agencies. Journal of Financial Economics, 76(2):309-330.

Kennan, J. and Riezman, R. (1988). Do Big Countries Win Tariff Wars? International Economic Review, 29(1):81-85. 
Kolari, J. W. and Pynnonen, S. (2011). Nonparametric rank tests for event studies. Journal of Empirical Finance, 18(5):953-971.

Krugman, P. R. (1987). Is free trade passé? Journal of Economic Perspectives, 1(2):131144.

Krugman, P. R., Obstfeld, M., and Melitz, M. (2018). International Economics: Theory and Policy. 11ed. Global Edition. Prentice Hall.

Lechthaler, W. and Mileva, M. (2018). Who Benefits from Trade Wars? Intereconomics, $53(1): 22-26$.

Lindé, J. and Pescatori, A. (2019). The macroeconomic effects of trade tariffs: Revisiting the lerner symmetry result. Journal of International Money and Finance, 95:52-69.

MacKinlay, A. C. (1997). Event studies in economics and finance. Journal of Economic Literature, 35(1):13-39.

Malatesta, P. H. (1983). The wealth effect of merger activity and the objective functions of merging firms. Journal of Financial Economics, 11(1-4):155-181.

Melitz, M. J. (2003). The impact of trade on intra-industry reallocations and aggregate industry productivity. Econometrica, 71(6):1695-1725.

Office of the United States Trade Representative (2018). Findings of the Investigation into China's Acts, Policies, and Practices related to technology transfer, intellectual property, and innovation und Section 301 of the Trade Act of 1974. Office of the United States Trade Representative Publications.

Office of the United States Trade Representative (2019). Notice of Determination and Action Pursuant to Section 301: Enforcement of U.S. WTO Rights in Large Civil Aircraft Dispute. Federal Register, 84:54245-54264.

Opp, M. M. (2010). Tariff wars in the Ricardian Model with a continuum of goods. Journal of International Economics, 80(2):212-225. 
Ossa, R. (2014). Trade wars and trade talks with data. American Economic Review, 104(12):4104-4146.

Pástor, L. and Veronesi, P. (2012). Uncertainty about government policy and stock prices. The Journal of Finance, 67(4):1219-1264.

Pástor, L. and Veronesi, P. (2013). Political uncertainty and risk premia. Journal of Financial Economics, 110(3):520-545.

Patell, J. M. (1976). Corporate forecasts of earnings per share and stock price behavior: Empirical test. Journal of accounting research, pages 246-276.

Pierce, J. R. and Schott, P. K. (2012). A concordance between ten-digit U.S. Harmonized System Codes and SIC/NAICS product classes and industries. Journal of Economic and Social Measurement, 37:61-96.

Qiu, L. D., Zhan, C., and Wei, X. (2019). An analysis of the China-US trade war through the lens of the trade literature. Economic and Political Studies, 7(2):148-168.

U.S. Department of Commerce (2018a). The Effect of Imports of Aluminum on the National Security. U.S. Department of Commerce Publications.

U.S. Department of Commerce (2018b). The Effect of Imports of Steel on the National Security. U.S. Department of Commerce Publications.

U.S. International Trade Commission (2017a). Crystalline Silicon Photovoltaic Cells (Whether or not Partially or Fully Assembled into Other Products) - Volume 1. U.S. International Trade Commission Publications Volume 4739.

U.S. International Trade Commission (2017b). Large Residential Washers. U.S. International Trade Commission Publications Volume 4745.

Wagner, A. F., Zeckhauser, R. J., and Ziegler, A. (2018). Company stock price reactions to the 2016 election shock: Trump, taxes, and trade. Journal of Financial Economics, 130(2):428-451. 


\section{Empirical appendix}

Figure 1: Development of the U.S. balance of trade from January 1997 until September 2019

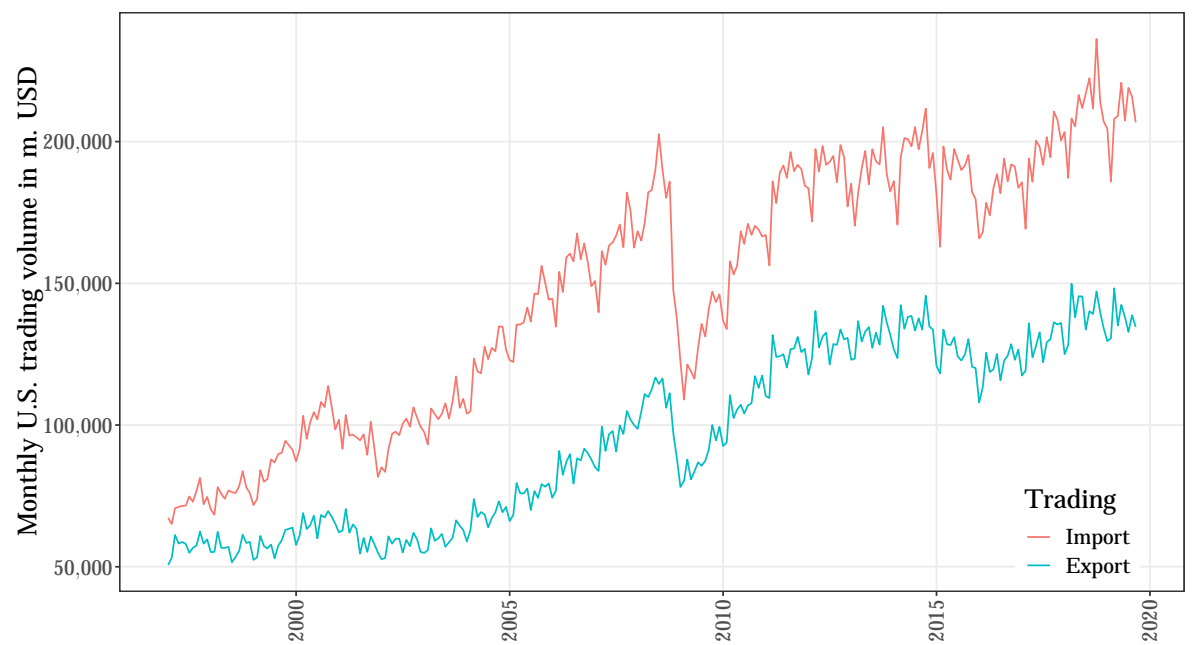

(a) This subfigure illustrates the monthly volumes of worldwide U.S. imports (red) and export (turquoise) volumes in millions of U.S. dollars (USD) from January 1997 to September 2019. The data is obtained from the United States Census Bureau.

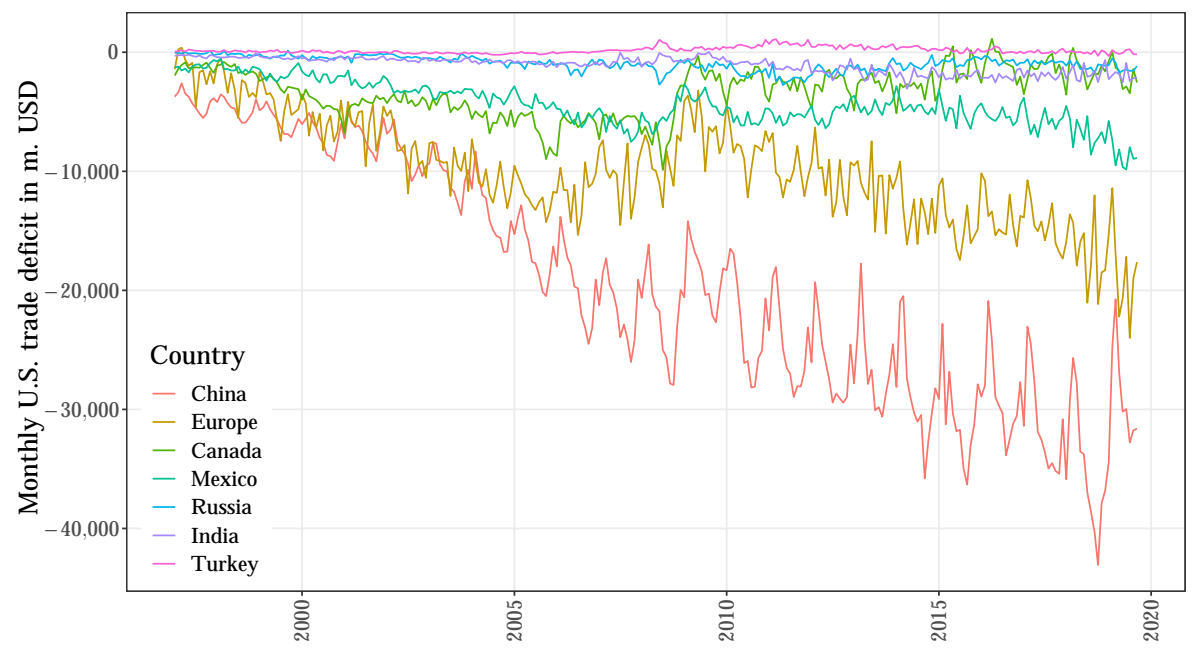

(b) This subfigure shows the monthly development of U.S. trade deficits in millions of U.S. dollars (USD) from January 1997 to September 2019 with regard to each country that is directly involved in recent tariff announcements by or against the U.S., respectively. The data is retrieved from the United States Census Bureau. 
Figure 2: Development of global trade tensions and the U.S. - China trade war

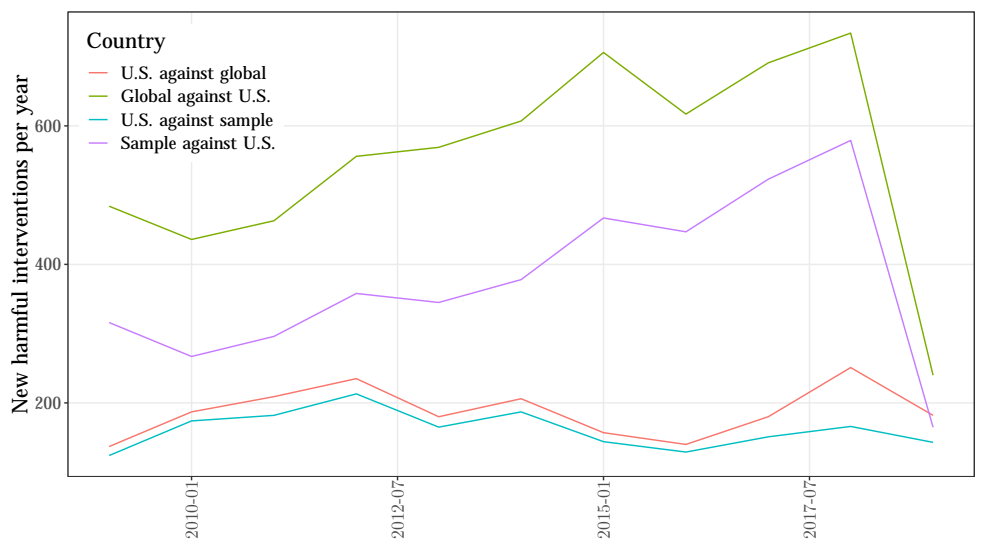

(a) This subfigure presents the number of new harmful interventions (subsidies, export-related measures, tariff measures, contingent tradeprotective measures, government procurement restrictions) imposed by (red, turquoise) and against (green, purple) the United States per year. The data is obtained from Global Trade Alert.

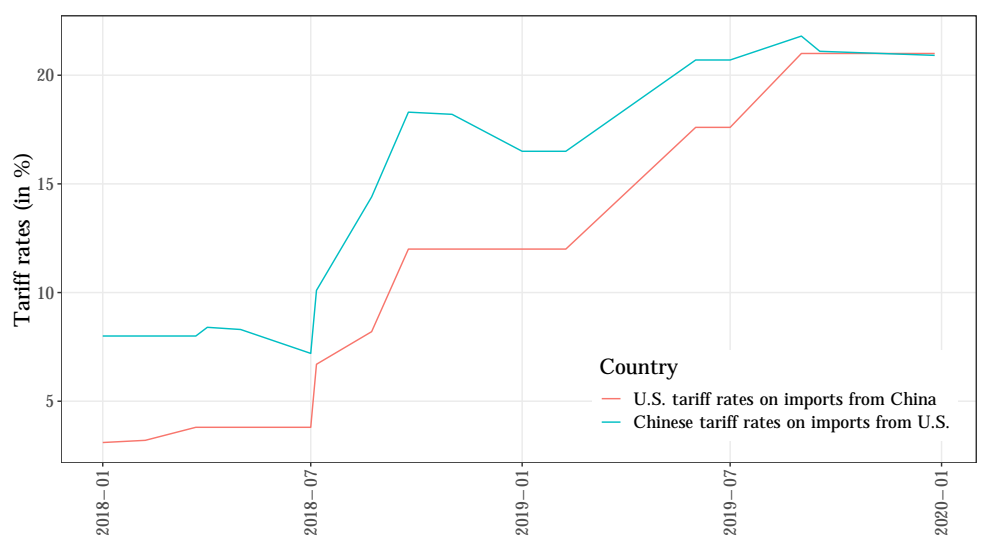

(b) This subfigure illustrates the development of tariff rates (in \%) during the trade war between the United States and China. The red line represents U.S. tariff rates on imports from China, while the turquoise line illustrates Chinese import tariffs on U.S. goods. The data is obtained from Bown and Kolb (2019).

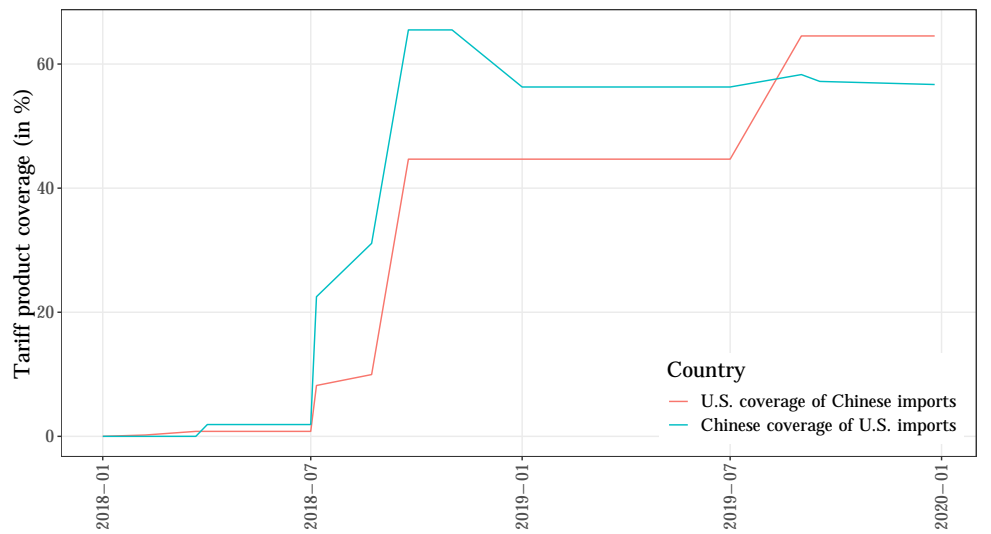

(c) This subfigure shows the development of production coverage of newly imposed tariffs throughout the trade war between the United States and China. The red line represents U.S. coverage of Chinese imports, while the turquoise line illustrates the Chinese import coverage of U.S. goods. The data is retrieved from the Peterson Institute for International Economics. 
Figure 3: Development of trade policy uncertainty

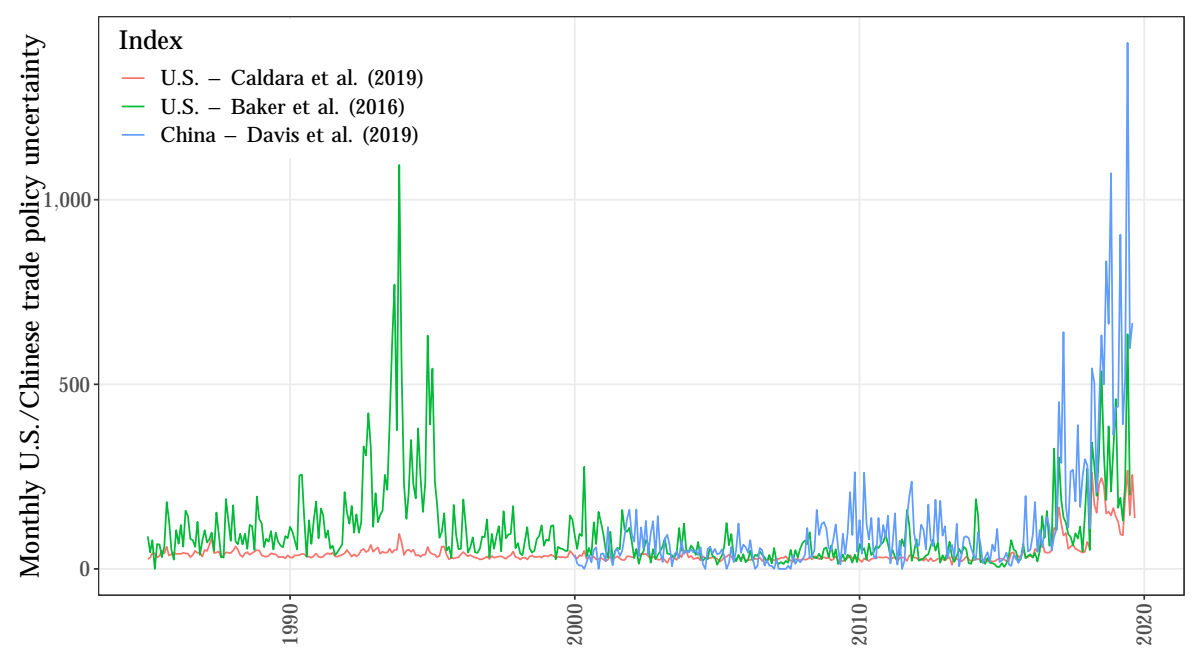

(a) This subfigure shows the monthly development of U.S. (red, green) and Chinese (blue) trade policy uncertainty (TPU). All TPU-indices are newspaper-based measures. The data is retrieved from Baker et al. (2016), Caldara et al. (2019) and Davis et al. (2019).

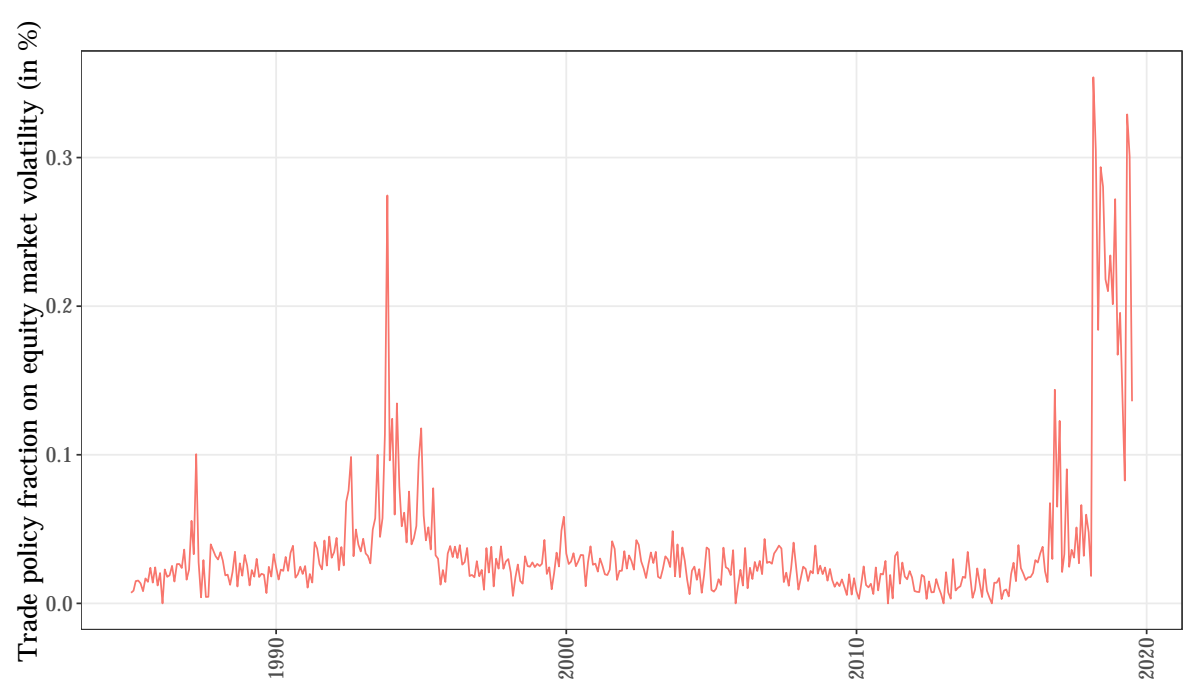

(b) Following Baker et al. (2019), this subfigure illustrates the fraction of equity market volatility (EMV) newspaper articles discussing trade policy affairs. The newspaperbased EMV-measure tracks the importance of trade policy concerns as a source of U.S. stock market volatility over time. 
Table 1: Harmonized Tariff Schedule of the United States

\begin{tabular}{clccc}
\hline \hline Section & Name & HTS chapters & $\mathrm{N}_{U S}$ & $\mathrm{~N}_{\text {Foreign }}$ \\
\hline 1 & Live animals, animal products & $1-5$ & 699 & 306 \\
2 & Vegetable products & $6-14$ & 567 & 482 \\
3 & Animal or vegetable fats and oils & 15 & 70 & 81 \\
4 & Prepared foodstuffs & $16-24$ & 799 & 460 \\
5 & Mineral products & $25-27$ & 204 & 203 \\
6 & Products of chemical or allied industries & $28-38$ & 1,595 & 1,221 \\
7 & Plastics, rubber and article thereof & $39-40$ & 372 & 312 \\
8 & Raw hides and skins, leather & $41-43$ & 228 & 124 \\
9 & Wood and articles of wood & $44-46$ & 273 & 233 \\
10 & Pulp of wood, paper & $47-49$ & 275 & 164 \\
11 & Textile and textile articles & $50-63$ & 1,680 & 1,102 \\
12 & Footwear, headgear, umbrellas etc. & $64-67$ & 197 & 89 \\
13 & Articles of stone, plaster, cement, & $68-70$ & 318 & 223 \\
& asbestos, mica, ceramic and glass & & & \\
14 & Pearls, precious stones and metals & 71 & 105 & 105 \\
15 & Base metals and articles thereof & $72-83$ & 988 & 1,072 \\
16 & Machinery, appliances, electrical equipment & $84-85$ & 1,383 & 1,482 \\
17 & Vehicles, aircraft, vessels & $86-89$ & 269 & 401 \\
18 & Optical, measuring, precision and medical & $90-92$ & 505 & 325 \\
19 & or surgical instruments & & & \\
21 & Arms and ammunition & $93-96$ & 294 & 195 \\
22 & Miscellaneous manufactured articles & 97 & 7 & 9 \\
\hline \hline
\end{tabular}

This table reports chapter and section listings of the Harmonized Tariff Schedule (HTS) codes. The number of announced U.S. and foreign tariffs for each HTS section is displayed in the columns $N_{U S}$ and $N_{F o r e i g n}$, respectively. All products are classified in 8-digit subheadings in order to standardize the HTS-classification. Section names are shown in abbreviated form. 
Table 2: Descriptive statistics

\begin{tabular}{lccccc}
\hline \hline Variable & Mean & Std. dev. & Min & Max & N \\
\hline Tariff characteristics & & & & & \\
Tariff rate & 0.1548 & 0.0795 & 0.0500 & 0.5000 & 2,738 \\
First announcement & 0.2331 & 0.4229 & 0.0000 & 1.0000 & 2,849 \\
\hline Trade characteristics & & & & & \\
Trade balance & 0.5841 & 0.4930 & 0.0000 & 1.0000 & 2,640 \\
Imports from China & 0.5462 & 0.4980 & 0.0000 & 1.0000 & 2,122 \\
Exports to China & 0.5688 & 0.4954 & 0.0000 & 1.0000 & 2,122 \\
\hline Firm characteristics & & & & & \\
Firm size (in m. $\$$ ) & $13,222.5553$ & $47,721.7081$ & 15.0265 & $860,882.4869$ & 2,848 \\
Performance (in $\$$ ) & 2.5501 & 13.1116 & -20.3600 & 279.4600 & 2,849 \\
Rating & 0.5515 & 0.4975 & 0.0000 & 1.0000 & 1,516 \\
\hline \hline
\end{tabular}

This table shows the summary statistics of the 2,849 identified tariff announcement events with regard to tariff, trade and firm characteristics between January 2018 and August 2019. The variables are described in Table 3. 
Table 3: Notes on variables and data sources

\begin{tabular}{lll}
\hline \hline Variable & Description & Data sources \\
\hline $\begin{array}{l}\text { Tariff characteristics } \\
\text { Tariff rate }\end{array}$ & $\begin{array}{l}\text { Government-announced tariff rate on specific types of goods and } \\
\text { services (HTS code) which are imported from other countries in } \\
\text { order to restrict trade and importation levels. }\end{array}$ & $\begin{array}{l}\text { Commerce, Ministry of Industry } \\
\text { and Trade of the Russian }\end{array}$ \\
& & Federation, WTO, European \\
& & Commission and Bown and Kolb \\
Tariff increase & Dummy variable that takes on the value of one if a tariff-increase & (2019) \\
& on specific goods and services (HTS code) is announced with & \\
regard to an already announced/imposed tariff within our & \\
observation period, and zero otherwise. & \\
First announcement & Dummy variable that takes on the value of one if a specific & \\
& NAICS classification code is affected by a tariff announcement & \\
& (HTS code) for the first time, and zero otherwise & \\
\hline
\end{tabular}


Table 3: Notes on variables and data sources (continued)

\begin{tabular}{lll}
\hline Variable & Description & Data sources \\
\hline $\begin{array}{l}\text { Trade characteristics } \\
\text { Trade balance }\end{array}$ & $\begin{array}{l}\text { Comparison of the aggregate values of U.S. imports from China } \\
\text { and U.S. exports to China per NAICS classification in 2017. The } \\
\text { dummy variable indicates whether a specific product group was }\end{array}$ & Data \\
& $\begin{array}{l}\text { subject to a trade deficit or trade surplus from the U.S. } \\
\text { perspective (value one), or not (value zero). }\end{array}$ & Hoberg-Moon Offshoring \\
& $\begin{array}{l}\text { Dummy variable that takes on the value of one if a U.S. firm } \\
\text { Imports from China }\end{array}$ & Repository database (Hoberg \\
& data is indexed by Compustat - Capital IQ's firm identifier gvkey. & and Moon, 2017, 2019), \\
& & Compustat - Capital IQ \\
Exports to China & $\begin{array}{l}\text { Dummy variable that takes on the value of one if a U.S. firm sold } \\
\text { goods to China in 2017, and zero otherwise. The data is indexed }\end{array}$ & \\
& by Compustat - Capital IQ's firm identifier gvkey. & \\
\hline
\end{tabular}


Table 3: Notes on variables and data sources (continued)

\begin{tabular}{lll}
\hline Variable & Description & Data sources \\
\hline $\begin{array}{l}\text { Firm characteristics } \\
\text { Firm size }\end{array}$ & $\begin{array}{l}\text { Product of the number of common shares outstanding and a U.S. } \\
\text { firm's share price (millions USD) in 2017. }\end{array}$ & Compustat - Capital IQ, CRSP \\
& $\begin{array}{l}\text { Accounting value of a U.S. firm's earnings per share (USD) in } \\
\text { Performance }\end{array}$ & \\
& 2017. & \\
Rating & $\begin{array}{l}\text { Dummy variable that takes on the value of one if a US firm's } \\
\text { average issuer rating of Moody's, Standard and Poors and Fitch }\end{array}$ & Refintiv's Eikon, own calc. \\
& Alphieved investment grade status in 2017, and zero otherwise. & \\
& $\begin{array}{l}\text { into an ordinal scale, starting with one as AAA and ending up } \\
\text { with } 23 \text { as the default category (Jorion et al., 2005). }\end{array}$ \\
\hline \hline
\end{tabular}


Table 4: (C)AARs from U.S. companies' stocks induced by the announcement of U.S. tariffs against foreign firms

\begin{tabular}{ccccc}
\hline \hline Days & (C)AARs (in \%) & GRANK-T & $\%>0$ & $\mathrm{~N}$ \\
\hline-1 & -0.1440 & -0.2473 & 48.3234 & 1,670 \\
0 & -0.4395 & $-4.0424^{* * *}$ & $35.2695^{* * *}$ & 1,670 \\
1 & -0.4033 & $-2.7541^{* * *}$ & $40.0000^{* * *}$ & 1,670 \\
\hline$[-1,1]$ & -0.9868 & $-4.5884^{* * *}$ & $33.2934^{* * *}$ & 1,670 \\
{$[-1,0]$} & -0.5835 & $-3.0955^{* * *}$ & $39.7006^{* * *}$ & 1,670 \\
{$[0,1]$} & -0.8428 & $-4.9311^{* * *}$ & $32.5150^{* * *}$ & 1,670 \\
\hline \hline
\end{tabular}

The upper part of the table reports the average abnormal stock returns (AARs) for a symmetric event window length of three trading days $([-1,1])$ around the respective announcement date $t_{0}$. The lower part shows the cumulative average abnormal stock returns (CAARs) across different event window lengths. 'GRANK-T' represents the t-statistics of the generalized rank test as proposed by Kolari and Pynnonen (2011). ' $\%>0$ ' is the percentage of positive (C)AARs for a given day or event window. Significances are tested with Pearsons chi-squared test of equal proportions. $N$ denotes the number of observations. ${ }^{* * *}, * *, *$ indicate statistical significance at the one-, five- and ten-percent level.

Figure 4: CAARs from U.S. companies' stocks induced by the announcement of U.S. tariffs against foreign firms

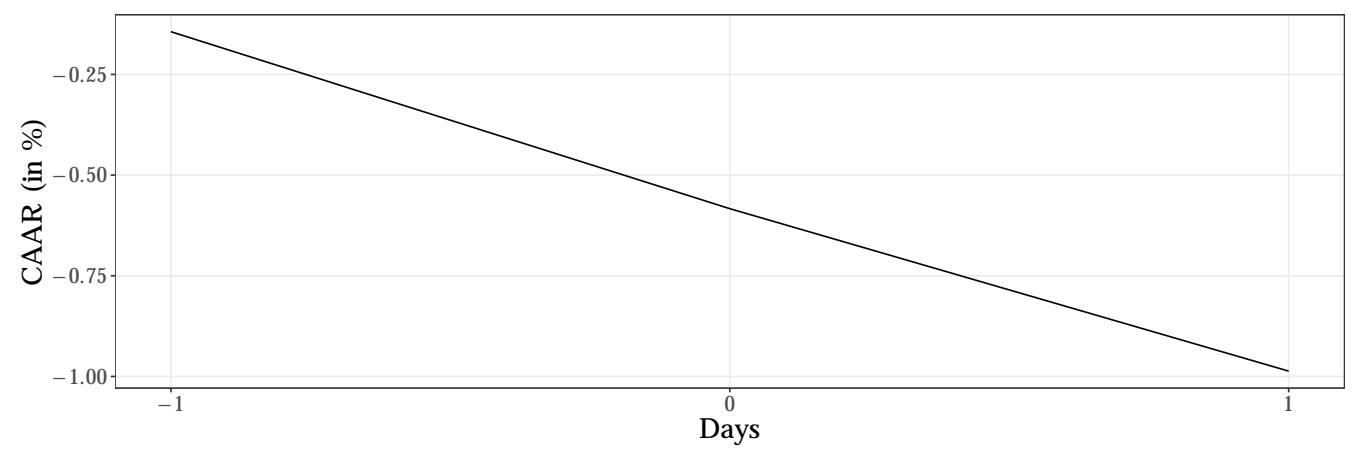

The figure refers to Table 4 and illustrates the development of the cumulative average abnormal stock returns (CAARs) within the main event window $[-1,1]$. 
Table 5: (C)AARs from U.S. companies' stocks induced by the announcement of foreign tariffs against U.S. firms

\begin{tabular}{ccccc}
\hline \hline Days & (C)AARs (in \%) & GRANK-T & $\%>0$ & $\mathrm{~N}$ \\
\hline-1 & -0.0202 & -0.1282 & $47.3282^{*}$ & 1,179 \\
0 & -0.6832 & $-4.1288^{* * *}$ & $33.3333^{* * *}$ & 1,179 \\
1 & 0.0893 & 0.3261 & 50.7209 & 1,179 \\
\hline$[-1,1]$ & -0.6141 & $-2.3607^{* *}$ & $38.9313^{* * *}$ & 1,179 \\
{$[-1,0]$} & -0.7034 & $-2.9855^{* * *}$ & $38.1679^{* * *}$ & 1,179 \\
{$[0,1]$} & -0.5939 & $-3.2703^{* * *}$ & $35.8779^{* * *}$ & 1,179 \\
\hline \hline
\end{tabular}

The upper part of the table reports the average abnormal stock returns (AARs) for a symmetric event window length of three trading days $([-1,1])$ around the respective announcement date $t_{0}$. The lower part shows the cumulative average abnormal stock returns (CAARs) across different event window lengths. 'GRANK-T' represents the t-statistics of the generalized rank test as proposed by Kolari and Pynnonen (2011). ' $\%>0$ ' is the percentage of positive (C)AARs for a given day or event window. Significances are tested with Pearsons chi-squared test of equal proportions. $N$ denotes the number of observations. ${ }^{* * *}, * *, *$ indicate statistical significance at the one-, five- and ten-percent level.

Figure 5: CAARs from U.S. companies' stocks induced by the announcement of foreign tariffs against U.S. firms

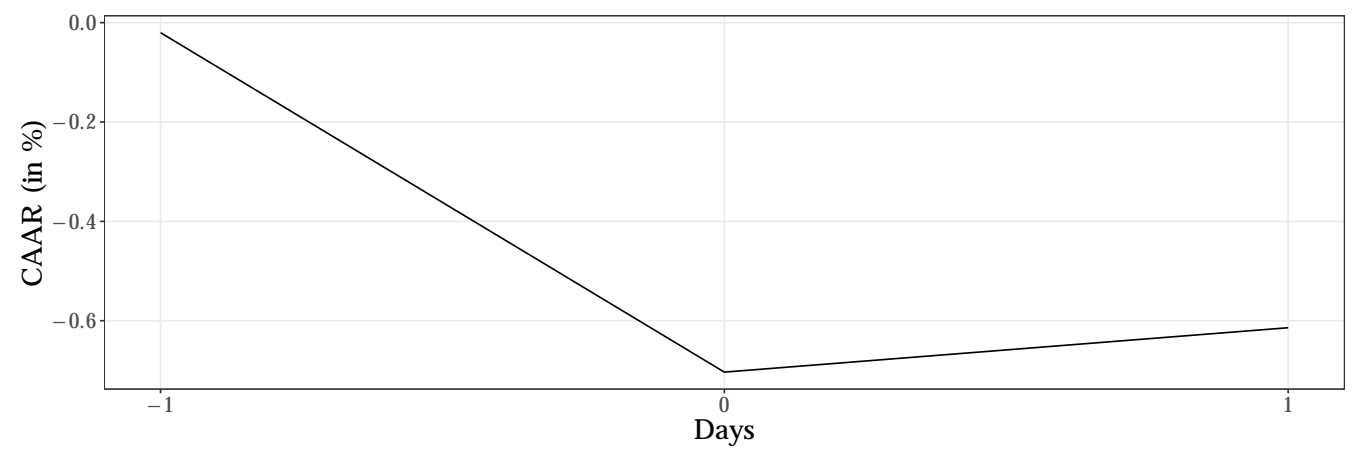

The figure refers to Table 5 and illustrates the development of the cumulative average abnormal stock returns (CAARs) within the main event window $[-1,1]$. 
Table 6: (C)AARs from U.S. companies' stocks induced by the announcement of U.S. tariffs against foreign firms (excluding China)

\begin{tabular}{ccccc}
\hline \hline Days & (C)AARs (in \%) & GRANK-T & $\%>0$ & $\mathrm{~N}$ \\
\hline-1 & -0.2284 & -0.0630 & 52.1212 & 165 \\
0 & -0.0717 & -0.6462 & $41.2121^{* *}$ & 165 \\
1 & -0.2040 & -0.3556 & 45.4545 & 165 \\
\hline$[-1,1]$ & -0.5041 & -0.5792 & $41.2121^{* *}$ & 165 \\
{$[-1,0]$} & -0.3001 & -0.3825 & 48.4848 & 165 \\
{$[0,1]$} & -0.2757 & -0.6532 & 46.6667 & 165 \\
\hline \hline
\end{tabular}

The upper part of the table reports the average abnormal stock returns (AARs) for a symmetric event window length of three trading days $([-1,1])$ around the respective announcement date $t_{0}$. The lower part shows the cumulative average abnormal stock returns (CAARs) across different event window lengths. 'GRANK-T' represents the t-statistics of the generalized rank test as proposed by Kolari and Pynnonen (2011). ' $\%>0$ ' is the percentage of positive (C)AARs for a given day or event window. Significances are tested with Pearsons chisquared test of equal proportions. $N$ denotes the number of observations. $* * *,{ }^{* *}, *$ indicate statistical significance at the one-, five- and ten-percent level.

Figure 6: CAARs from U.S. companies' stocks induced by the announcement of U.S. tariffs against foreign firms (excluding China)

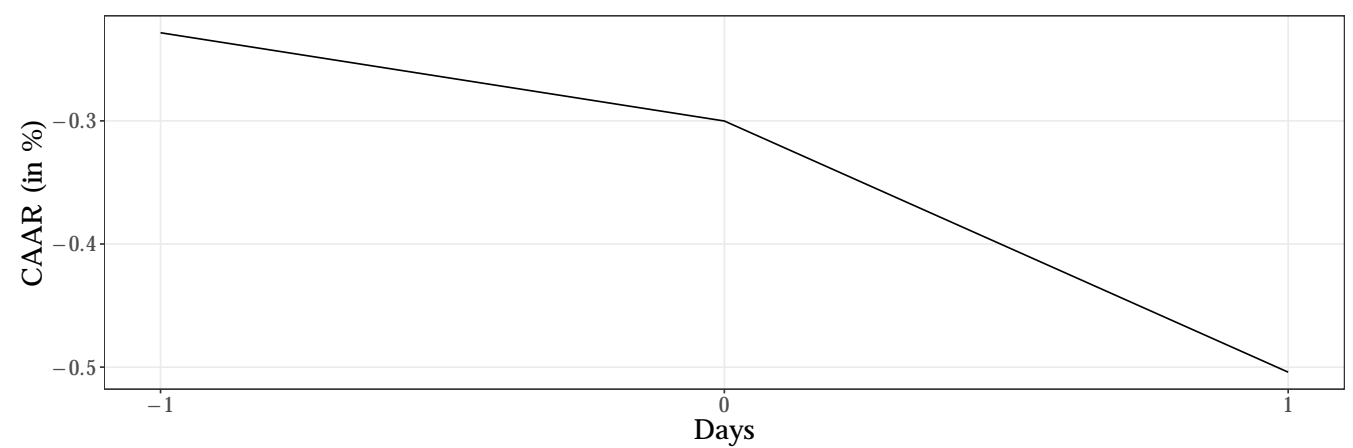

The figure refers to Table 6 and illustrates the development of the cumulative average abnormal stock returns (CAARs) within the main event window $[-1,1]$. 
Table 7: (C)AARs from U.S. companies' stocks induced by the announcement of foreign tariffs (excluding China) against U.S. firms

\begin{tabular}{ccccc}
\hline \hline Days & (C)AARs (in \%) & GRANK-T & $\%>0$ & $\mathrm{~N}$ \\
\hline-1 & 0.1304 & 0.6290 & 51.5528 & 322 \\
0 & -0.1343 & -0.5866 & 50.0000 & 322 \\
1 & 0.0552 & 0.4466 & 51.5528 & 322 \\
\hline$[-1,1]$ & 0.0513 & 0.0657 & 50.6211 & 322 \\
{$[-1,0]$} & -0.0039 & -0.3087 & 49.0683 & 322 \\
{$[0,1]$} & -0.0791 & -0.2716 & 48.4472 & 322 \\
\hline \hline
\end{tabular}

The upper part of the table reports the average abnormal stock returns (AARs) for a symmetric event window length of three trading days $([-1,1])$ around the respective announcement date $t_{0}$. The lower part shows the cumulative average abnormal stock returns (CAARs) across different event window lengths. 'GRANK-T' represents the t-statistics of the generalized rank test as proposed by Kolari and Pynnonen (2011). ' $\%>0$ ' is the percentage of positive (C)AARs for a given day or event window. Significances are tested with Pearsons chi-squared test of equal proportions. $N$ denotes the number of observations. $* * *, * *, *$ indicate statistical significance at the one-, five- and ten-percent level.

Figure 7: CAARs from U.S. companies' stocks induced by the announcement of foreign tariffs (excluding China) against U.S. firms

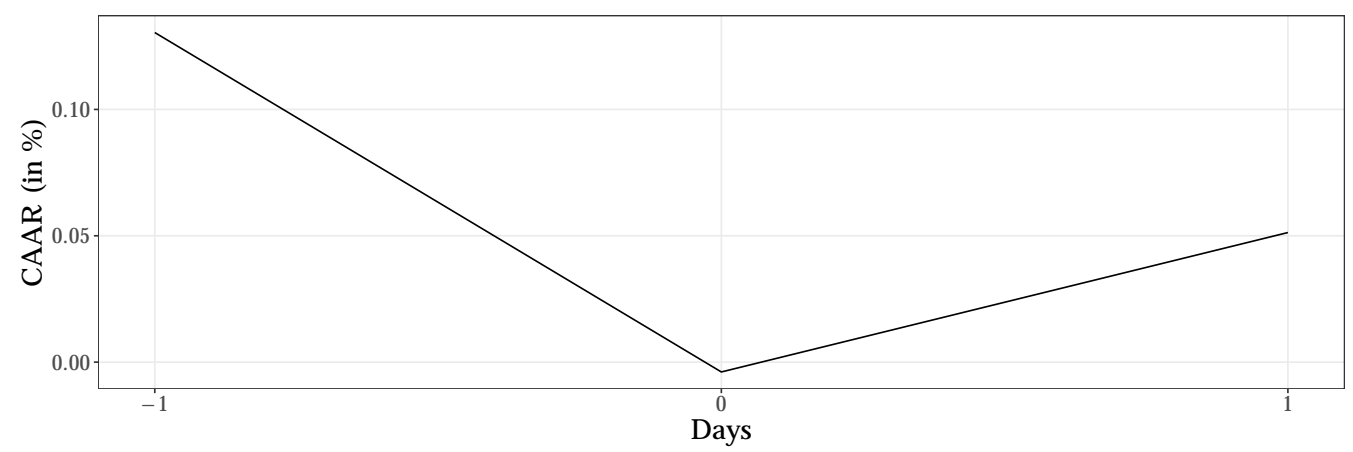

The figure refers to Table 7 and illustrates the development of the cumulative average abnormal stock returns (CAARs) within the main event window $[-1,1]$. 
Table 8: (C)AARs from U.S. companies' stocks induced by the announcement of U.S. tariffs against Chinese firms Aggregated tariff rounds 1-4

\begin{tabular}{ccccc}
\hline \hline Days & (C)AARs (in \%) & GRANK-T & $\%>0$ & $\mathrm{~N}$ \\
\hline-1 & -0.1347 & -0.2365 & 47.9070 & 1,505 \\
0 & -0.4798 & $-4.0508^{* * *}$ & $34.6179^{* * *}$ & 1,505 \\
1 & -0.4252 & $-2.7757^{* * *}$ & $39.4020^{* * *}$ & 1,505 \\
\hline$[-1,1]$ & -1.0397 & $-4.6458^{* * *}$ & $32.4252^{* * *}$ & 1,505 \\
{$[-1,0]$} & -0.6145 & $-3.1066^{* * *}$ & $38.7375^{* * *}$ & 1,505 \\
{$[0,1]$} & -0.9050 & $-4.9747^{* * *}$ & $30.9635^{* * *}$ & 1,505 \\
\hline \hline
\end{tabular}

The upper part of the table reports the average abnormal stock returns (AARs) for a symmetric event window length of three trading days ([-1,1]) around the respective announcement date $t_{0}$. The lower part shows the cumulative average abnormal stock returns (CAARs) across different event window lengths. 'GRANK-T' represents the t-statistics of the generalized rank test as proposed by Kolari and Pynnonen (2011). ' $\%>0$ ' is the percentage of positive (C)AARs for a given day or event window. Significances are tested with Pearsons chi-squared test of equal proportions. $N$ denotes the number of observations. ${ }^{* * *}, * * *$ indicate statistical significance at the one-, five- and ten-percent level.

Figure 8: CAARs from U.S. companies' stocks induced by the announcement of U.S. tariffs against Chinese firms - Aggregated tariff rounds 1-4

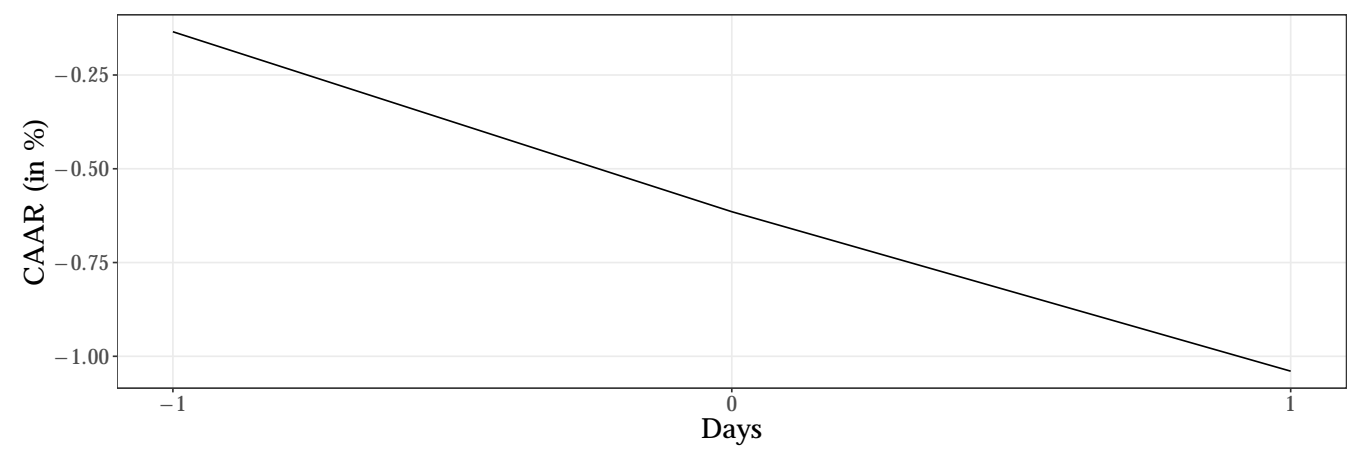

The figure refers to Table 8 and illustrates the development of the cumulative average abnormal stock returns (CAARs) within the main event window $[-1,1]$. 
Table 9: (C)AARs from U.S. companies' stocks induced by the announcement of Chinese tariffs against U.S. firms - Aggregated tariff rounds 1-4

\begin{tabular}{ccccc}
\hline \hline Days & (C)AARs (in \%) & GRANK-T & $\%>0$ & $\mathrm{~N}$ \\
\hline-1 & -0.0841 & -0.3037 & $45.5516^{* *}$ & 843 \\
0 & -0.9129 & $-3.9504^{* * *}$ & $26.4531^{* * *}$ & 843 \\
1 & 0.1143 & 0.1853 & 50.5338 & 843 \\
\hline$[-1,1]$ & -0.8827 & $-2.4185^{* *}$ & $34.0451^{* * *}$ & 843 \\
{$[-1,0]$} & -0.9970 & $-2.8925^{* * *}$ & $33.4520^{* * *}$ & 843 \\
{$[0,1]$} & -0.7986 & $-3.1839^{* * *}$ & $30.9609^{* * *}$ & 843 \\
\hline \hline
\end{tabular}

The upper part of the table reports the average abnormal stock returns (AARs) for a symmetric event window length of three trading days $([-1,1])$ around the respective announcement date $t_{0}$. The lower part shows the cumulative average abnormal stock returns (CAARs) across different event window lengths. 'GRANK-T' represents the t-statistics of the generalized rank test as proposed by Kolari and Pynnonen (2011). ' $\%>0$ ' is the percentage of positive (C)AARs for a given day or event window. Significances are tested with Pearsons chi-squared test of equal proportions. $N$ denotes the number of observations. ${ }^{* * *},{ }^{* *}, *$ indicate statistical significance at the one-, five- and ten-percent level.

Figure 9: CAARs from U.S. companies' stocks induced by the announcement of Chinese tariffs against U.S. firms - Aggregated tariff rounds 1-4

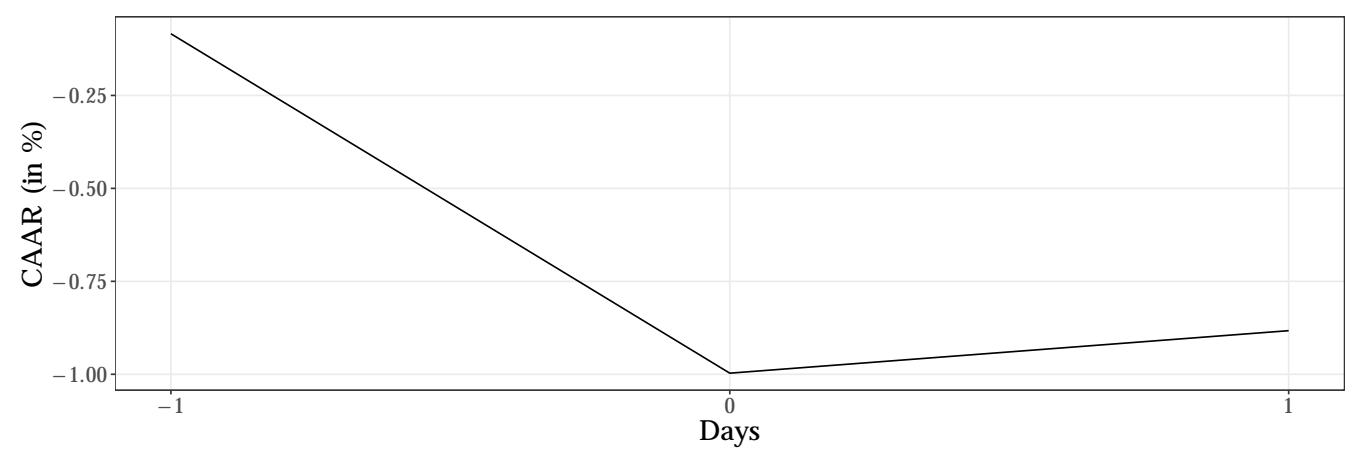

The figure refers to Table 9 and illustrates the development of the cumulative average abnormal stock returns (CAARs) within the main event window $[-1,1]$. 
Table 10: (C)AARs from U.S. companies' stocks induced by the announcement of U.S. tariffs against Chinese firms - Round 1

\begin{tabular}{ccccc}
\hline \hline Days & (C)AARs (in \%) & GRANK-T & $\%>0$ & $\mathrm{~N}$ \\
\hline-1 & -0.4449 & -1.2422 & $40.4692^{* * *}$ & 341 \\
0 & -0.4662 & $-3.0549 * * *$ & $29.3255^{* * *}$ & 341 \\
1 & -0.5400 & -1.0254 & $42.2287^{* * *}$ & 341 \\
\hline$[-1,1]$ & -1.4511 & $-3.2057^{* * *}$ & $31.0850^{* * *}$ & 341 \\
{$[-1,0]$} & -0.9111 & $-3.3157^{* * *}$ & $30.4985^{* * *}$ & 341 \\
{$[0,1]$} & -1.0062 & $-2.9065^{* * *}$ & $30.2053^{* * *}$ & 341 \\
\hline \hline
\end{tabular}

The upper part of the table reports the average abnormal stock returns (AARs) for a symmetric event window length of three trading days ([-1,1]) around the respective announcement date $t_{0}$. The lower part shows the cumulative average abnormal stock returns (CAARs) across different event window lengths. 'GRANK-T' represents the t-statistics of the generalized rank test as proposed by Kolari and Pynnonen (2011). ' $\%>0$ ' is the percentage of positive (C)AARs for a given day or event window. Significances are tested with Pearsons chi-squared test of equal proportions. $N$ denotes the number of observations. ${ }^{* * *},{ }^{* *}, *$ indicate statistical significance at the one-, five- and ten-percent level.

Figure 10: CAARs from U.S. companies' stocks induced by the announcement of U.S. tariffs against Chinese firms - Round 1

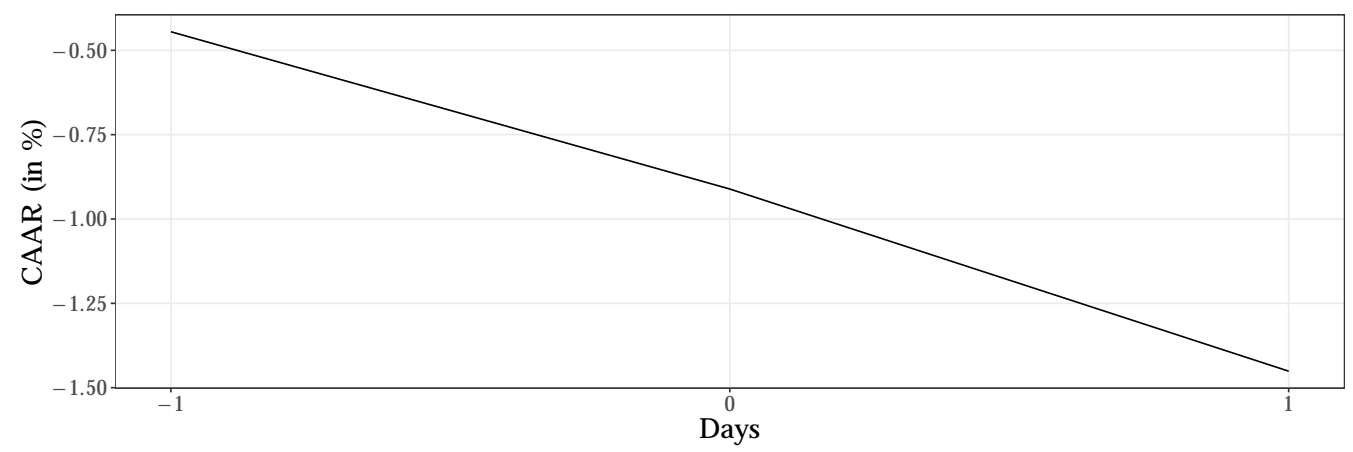

The figure refers to Table 10 and illustrates the development of the cumulative average abnormal stock returns (CAARs) within the main event window $[-1,1]$. 
Table 11: (C)AARs from U.S. companies' stocks induced by the announcement of Chinese tariffs against U.S. firms - Round 1

\begin{tabular}{ccccc}
\hline \hline Days & (C)AARs (in \%) & GRANK-T & $\%>0$ & $\mathrm{~N}$ \\
\hline-1 & 0.1046 & 0.4054 & 51.3514 & 37 \\
0 & -0.1481 & -0.9716 & 40.5405 & 37 \\
1 & -0.2390 & -0.6723 & 45.9459 & 37 \\
\hline$[-1,1]$ & -0.2825 & -1.0295 & 40.5405 & 37 \\
{$[-1,0]$} & -0.0435 & -0.7588 & 37.8378 & 37 \\
{$[0,1]$} & -0.3871 & -1.4098 & $32.4324^{* *}$ & 37 \\
\hline \hline
\end{tabular}

The upper part of the table reports the average abnormal stock returns (AARs) for a symmetric event window length of three trading days $([-1,1])$ around the respective announcement date $t_{0}$. The lower part shows the cumulative average abnormal stock returns (CAARs) across different event window lengths. 'GRANK-T' represents the t-statistics of the generalized rank test as proposed by Kolari and Pynnonen (2011). ' $\%>0$ ' is the percentage of positive (C)AARs for a given day or event window. Significances are tested with Pearsons chi-squared test of equal proportions. $N$ denotes the number of observations. ${ }^{* * *}, * *, *$ indicate statistical significance at the one-, five- and ten-percent level.

Figure 11: CAARs from U.S. companies' stocks induced by the announcement of Chinese tariffs against U.S. firms - Round 1

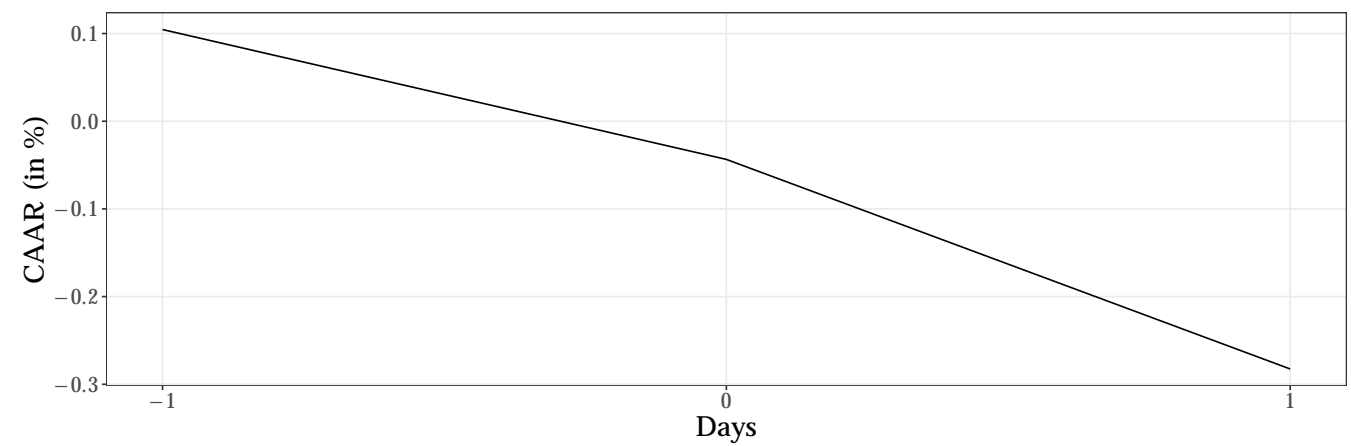

The figure refers to Table 11 and illustrates the development of the cumulative average abnormal stock returns (CAARs) within the main event window $[-1,1]$. 
Table 12: (C)AARs from U.S. companies' stocks induced by the announcement of U.S. tariffs against Chinese firms - Round 2

\begin{tabular}{ccccc}
\hline \hline Days & (C)AARs (in \%) & GRANK-T & $\%>0$ & $\mathrm{~N}$ \\
\hline-1 & -0.1532 & -0.3421 & 46.1957 & 184 \\
0 & -0.5803 & $-1.8972^{*}$ & $32.6087^{* * *}$ & 184 \\
1 & -0.6316 & $-2.6256^{* * *}$ & $26.6304^{* * *}$ & 184 \\
\hline$[-1,1]$ & -1.3651 & $-2.5794^{* *}$ & $27.7174^{* * *}$ & 184 \\
{$[-1,0]$} & -0.7335 & -1.4383 & $36.9565^{* * *}$ & 184 \\
{$[0,1]$} & -1.2119 & $-3.1512^{* * *}$ & $23.3696^{* * *}$ & 184 \\
\hline \hline
\end{tabular}

The upper part of the table reports the average abnormal stock returns (AARs) for a symmetric event window length of three trading days ([-1,1]) around the respective announcement date $t_{0}$. The lower part shows the cumulative average abnormal stock returns (CAARs) across different event window lengths. 'GRANK-T' represents the t-statistics of the generalized rank test as proposed by Kolari and Pynnonen (2011). ' $\%>0$ ' is the percentage of positive (C)AARs for a given day or event window. Significances are tested with Pearsons chi-squared test of equal proportions. $N$ denotes the number of observations. ${ }^{* * *},{ }^{* *}, *$ indicate statistical significance at the one-, five- and ten-percent level.

Figure 12: CAARs from U.S. companies' stocks induced by the announcement of U.S. tariffs against Chinese firms - Round 2

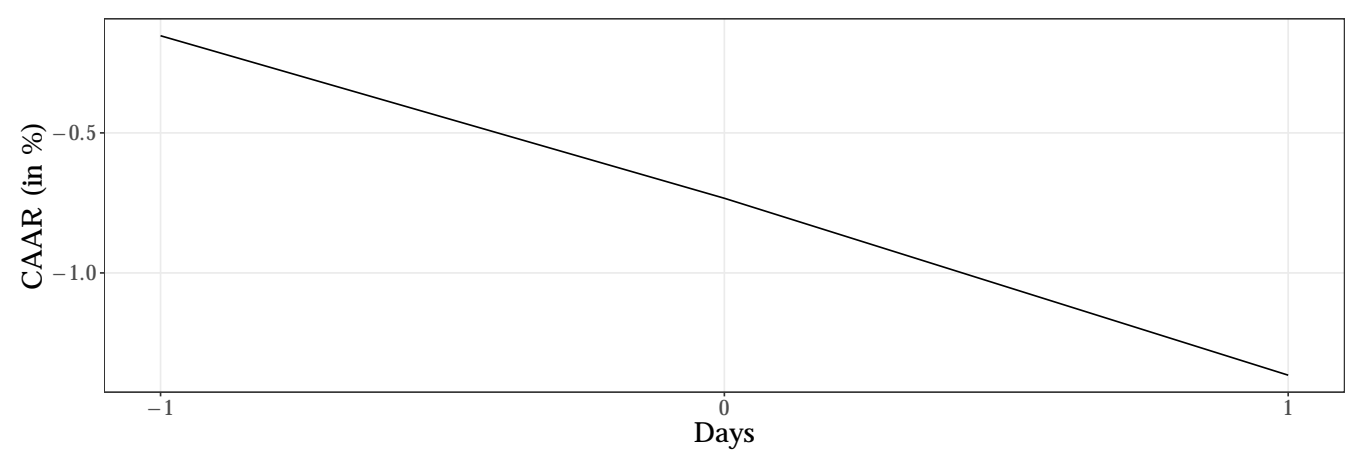

The figure refers to Table 12 and illustrates the development of the cumulative average abnormal stock returns (CAARs) within the main event window $[-1,1]$. 
Table 13: (C)AARs from U.S. companies' stocks induced by the announcement of Chinese tariffs against U.S. firms - Round 2

\begin{tabular}{ccccc}
\hline \hline Days & (C)AARs (in \%) & GRANK-T & $\%>0$ & $\mathrm{~N}$ \\
\hline-1 & -0.1051 & -0.1347 & 46.4706 & 170 \\
0 & -1.5012 & $-2.5653^{* *}$ & $23.5294^{* * *}$ & 170 \\
1 & 0.2358 & 0.1836 & 49.4118 & 170 \\
\hline$[-1,1]$ & -1.3705 & $-1.7852^{*}$ & $32.9412^{* * *}$ & 170 \\
{$[-1,0]$} & -1.6063 & $-1.9791^{* *}$ & $32.3529^{* * *}$ & 170 \\
{$[0,1]$} & -1.2654 & $-2.2725^{* *}$ & $27.6471^{* * *}$ & 170 \\
\hline \hline
\end{tabular}

The upper part of the table reports the average abnormal stock returns (AARs) for a symmetric event window length of three trading days ([-1,1]) around the respective announcement date $t_{0}$. The lower part shows the cumulative average abnormal stock returns (CAARs) across different event window lengths. 'GRANK-T' represents the t-statistics of the generalized rank test as proposed by Kolari and Pynnonen (2011). ' $\%>0$ ' is the percentage of positive (C)AARs for a given day or event window. Significances are tested with Pearsons chi-squared test of equal proportions. $N$ denotes the number of observations. ${ }^{* * *},{ }^{* *}, *$ indicate statistical significance at the one-, five- and ten-percent level.

Figure 13: CAARs from U.S. companies' stocks induced by the announcement of Chinese tariffs against U.S. firms - Round 2

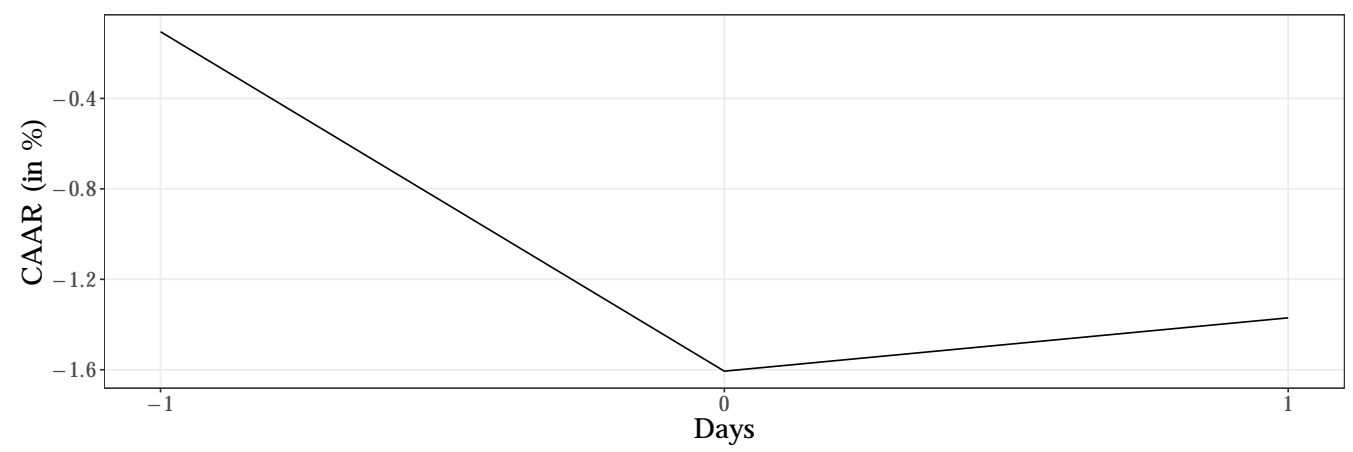

The figure refers to Table 13 and illustrates the development of the cumulative average abnormal stock returns (CAARs) within the main event window $[-1,1]$. 
Table 14: (C)AARs from U.S. companies' stocks induced by the announcement of U.S. tariffs against Chinese firms - Round 3

\begin{tabular}{ccccc}
\hline \hline Days & (C)AARs (in \%) & GRANK-T & $\%>0$ & $\mathrm{~N}$ \\
\hline-1 & 0.0166 & 0.6137 & 53.2925 & 653 \\
0 & -0.3763 & $-1.8203^{*}$ & $38.1317^{* * *}$ & 653 \\
1 & -0.4386 & $-2.1540^{* *}$ & $37.6723^{* * *}$ & 653 \\
\hline$[-1,1]$ & -0.7983 & $-2.9411^{* * *}$ & $31.853^{* * *}$ & 653 \\
{$[-1,0]$} & -0.3597 & -0.8640 & $44.4104^{* * *}$ & 653 \\
{$[0,1]$} & -0.8149 & $-3.0348^{* * *}$ & $31.5467^{* * *}$ & 653 \\
\hline \hline
\end{tabular}

The upper part of the table reports the average abnormal stock returns (AARs) for a symmetric event window length of three trading days $([-1,1])$ around the respective announcement date $t_{0}$. The lower part shows the cumulative average abnormal stock returns (CAARs) across different event window lengths. 'GRANK-T' represents the t-statistics of the generalized rank test as proposed by Kolari and Pynnonen (2011). ' $\%>0$ ' is the percentage of positive (C)AARs for a given day or event window. Significances are tested with Pearsons chi-squared test of equal proportions. $N$ denotes the number of observations. ${ }^{* * *},{ }^{* *}, *$ indicate statistical significance at the one-, five- and ten-percent level.

Figure 14: CAARs from U.S. companies' stocks induced by the announcement of U.S. tariffs against Chinese firms - Round 3

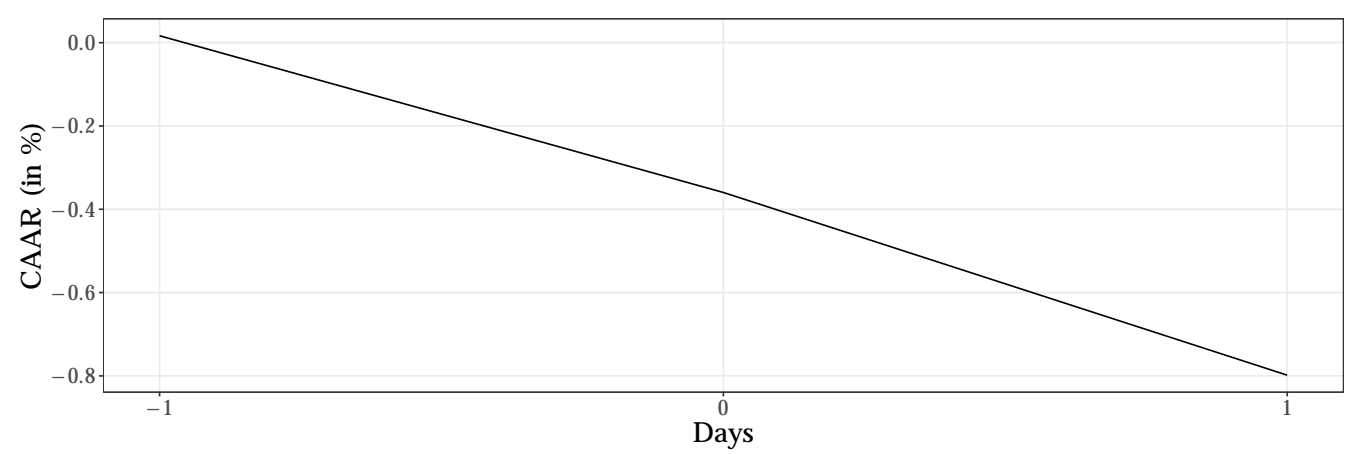

The figure refers to Table 14 and illustrates the development of the cumulative average abnormal stock returns (CAARs) within the main event window $[-1,1]$. 
Table 15: (C)AARs from U.S. companies' stocks induced by the announcement of Chinese tariffs against U.S. firms - Round 3

\begin{tabular}{ccccc}
\hline \hline Days & (C)AARs (in \%) & GRANK-T & $\%>0$ & $\mathrm{~N}$ \\
\hline-1 & -0.0707 & -0.2670 & $44.9111^{* *}$ & 619 \\
0 & -0.8000 & $-3.1213^{* * *}$ & $26.1712^{* * *}$ & 619 \\
1 & 0.0851 & 0.1345 & 50.5654 & 619 \\
\hline$[-1,1]$ & -0.7856 & $-1.8067^{*}$ & $33.9257^{* * *}$ & 619 \\
{$[-1,0]$} & -0.8707 & $-2.2088^{* *}$ & $33.9257^{* * *}$ & 619 \\
{$[0,1]$} & -0.7149 & $-2.3987^{* *}$ & $31.8255^{* * *}$ & 619 \\
\hline \hline
\end{tabular}

The upper part of the table reports the average abnormal stock returns (AARs) for a symmetric event window length of three trading days ([-1,1]) around the respective announcement date $t_{0}$. The lower part shows the cumulative average abnormal stock returns (CAARs) across different event window lengths. 'GRANK-T' represents the t-statistics of the generalized rank test as proposed by Kolari and Pynnonen (2011). ' $\%>0$ ' is the percentage of positive (C)AARs for a given day or event window. Significances are tested with Pearsons chi-squared test of equal proportions. $N$ denotes the number of observations. ${ }^{* * *}, * *, *$ indicate statistical significance at the one-, five- and ten-percent level.

Figure 15: CAARs from U.S. companies' stocks induced by the announcement of Chinese tariffs against U.S. firms - Round 3

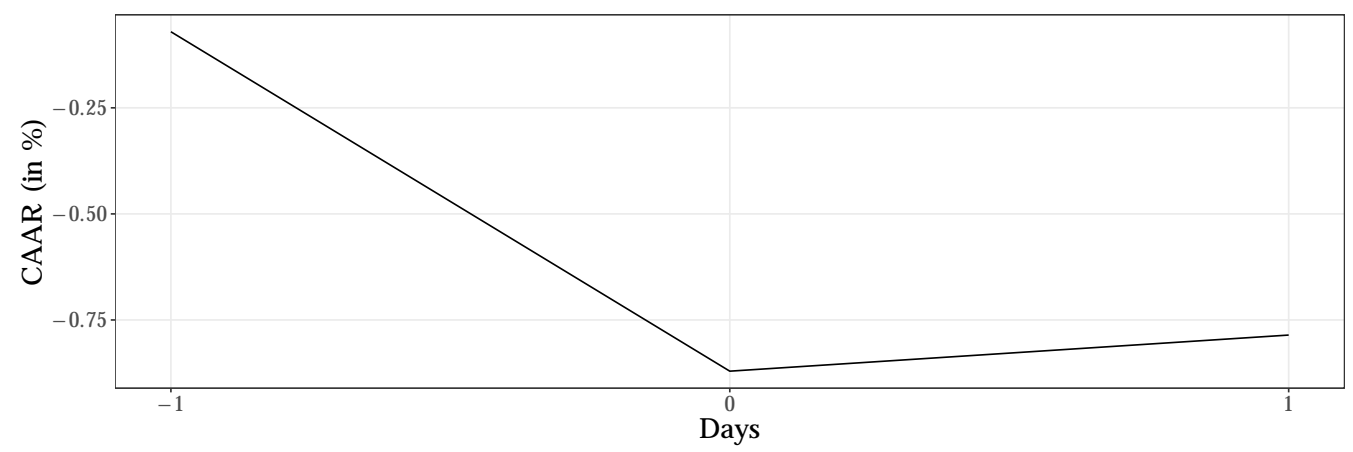

The figure refers to Table 15 and illustrates the development of the cumulative average abnormal stock returns (CAARs) within the main event window $[-1,1]$. 
Table 16: (C)AARs from U.S. companies' stocks induced by the announcement of U.S. tariffs against Chinese firms - Round 4

\begin{tabular}{ccccc}
\hline \hline Days & (C)AARs (in \%) & GRANK-T & $\%>0$ & $\mathrm{~N}$ \\
\hline-1 & -0.1029 & -0.3883 & 45.8716 & 327 \\
0 & -0.6441 & $-2.5933^{* *}$ & $34.2508^{* * *}$ & 327 \\
1 & -0.1625 & -0.5412 & 47.0948 & 327 \\
\hline$[-1,1]$ & -0.9095 & $-1.7698^{*}$ & $37.6147^{* * *}$ & 327 \\
{$[-1,0]$} & -0.7470 & $-1.9834^{* *}$ & $37.0031^{* * *}$ & 327 \\
{$[0,1]$} & -0.8066 & $-2.0819^{* *}$ & $34.8624^{* * *}$ & 327 \\
\hline \hline
\end{tabular}

The upper part of the table reports the average abnormal stock returns (AARs) for a symmetric event window length of three trading days ([-1,1]) around the respective announcement date $t_{0}$. The lower part shows the cumulative average abnormal stock returns (CAARs) across different event window lengths. 'GRANK-T' represents the t-statistics of the generalized rank test as proposed by Kolari and Pynnonen (2011). ' $\%>0$ ' is the percentage of positive (C)AARs for a given day or event window. Significances are tested with Pearsons chi-squared test of equal proportions. $N$ denotes the number of observations. ${ }^{* * *}, * *, *$ indicate statistical significance at the one-, five- and ten-percent level.

Figure 16: CAARs from U.S. companies' stocks induced by the announcement of U.S. tariffs against Chinese firms - Round 4

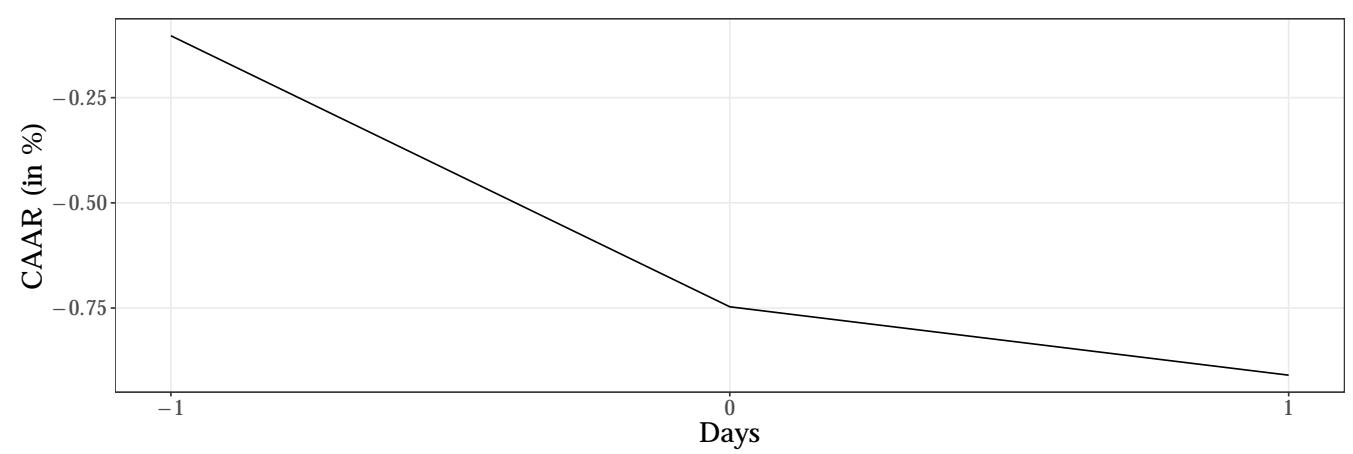

The figure refers to Table 16 and illustrates the development of the cumulative average abnormal stock returns (CAARs) within the main event window $[-1,1]$. 
Table 17: (C)AARs from U.S. companies' stocks induced by the announcement of Chinese tariffs against U.S. firms - Round 4

\begin{tabular}{ccccc}
\hline \hline Days & (C)AARs (in \%) & GRANK-T & $\%>0$ & $\mathrm{~N}$ \\
\hline-1 & -0.7730 & -0.6829 & 47.0588 & 17 \\
0 & -0.8057 & $-2.4023^{* *}$ & 35.2941 & 17 \\
1 & 0.7322 & 1.3149 & 70.5882 & 17 \\
\hline$[-1,1]$ & -0.8465 & -1.4650 & 35.2941 & 17 \\
{$[-1,0]$} & -1.5787 & $-2.4989^{* *}$ & $17.6471^{* *}$ & 17 \\
{$[0,1]$} & -0.0735 & -1.3669 & 29.4118 & 17 \\
\hline \hline
\end{tabular}

The upper part of the table reports the average abnormal stock returns (AARs) for a symmetric event window length of three trading days $([-1,1])$ around the respective announcement date $t_{0}$. The lower part shows the cumulative average abnormal stock returns (CAARs) across different event window lengths. 'GRANK-T' represents the t-statistics of the generalized rank test as proposed by Kolari and Pynnonen (2011). ' $\%>0$ ' is the percentage of positive (C)AARs for a given day or event window. Significances are tested with Pearsons chi-squared test of equal proportions. $N$ denotes the number of observations. ${ }^{* * *}, * *, *$ indicate statistical significance at the one-, five- and ten-percent level.

Figure 17: CAARs from U.S. companies' stocks induced by the announcement of Chinese tariffs against U.S. firms - Round 4

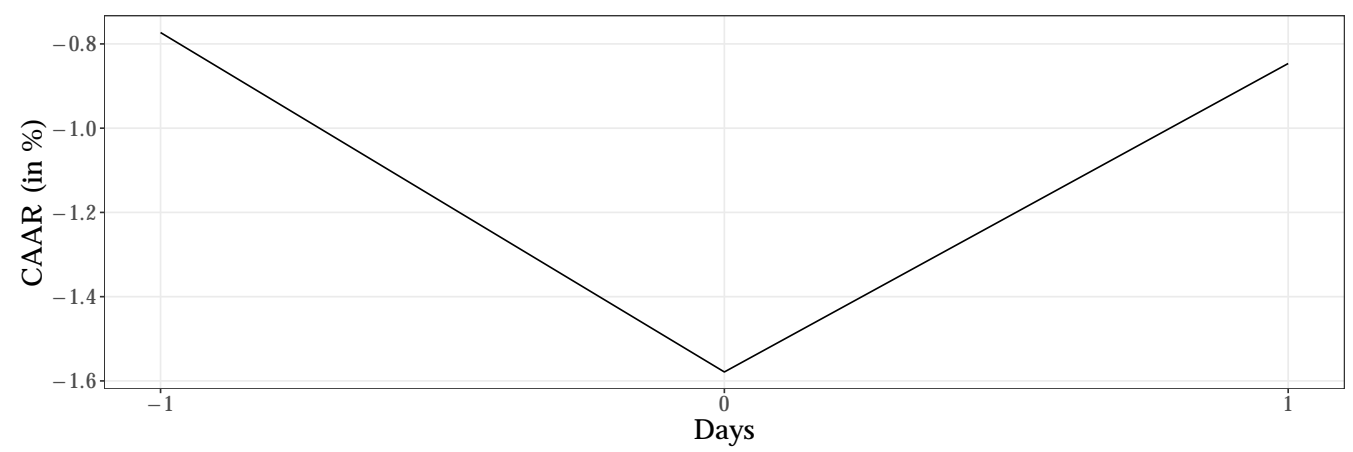

The figure refers to Table 17 and illustrates the development of the cumulative average abnormal stock returns (CAARs) within the main event window $[-1,1]$. 
Table 18: Model robustness

\begin{tabular}{|c|c|c|c|c|}
\hline & $\operatorname{CAAR}_{[-1,1]}($ in $\%)$ & Difference (in \%) & $\%>0$ & $\mathrm{~N}$ \\
\hline \multicolumn{5}{|l|}{ U.S. tariff rounds against China } \\
\hline Baseline & $-1.0397 * * *$ & - & $32.4252^{* * *}$ & 1,505 \\
\hline Carhart four-factor model & $-0.9902^{* * *}$ & -0.0495 & $32.7575^{* * *}$ & 1,505 \\
\hline 100 days estimation window & $-0.9625^{* * *}$ & -0.0772 & $33.5995^{* * *}$ & 1,628 \\
\hline 400 days estimation window & $-0.9690^{* * *}$ & -0.0707 & $32.0596^{* * *}$ & 1,073 \\
\hline Daily return boundary: $+/-50 \%$ & $-1.1780^{* * *}$ & 0.1383 & $32.8261^{* * *}$ & 1,840 \\
\hline Pennystock & $-1.0636^{* * *}$ & 0.0239 & $32.3934^{* * *}$ & 1,525 \\
\hline Standard Industrial Classification (SIC) & $-1.1188^{* * *}$ & 0.0791 & $31.3458^{* * *}$ & 1,174 \\
\hline \multicolumn{5}{|l|}{ Chinese tariff rounds against U.S. } \\
\hline Baseline & $-0.8827^{* *}$ & - & $34.0451^{* * *}$ & 843 \\
\hline Carhart four-factor model & $-0.9288^{* *}$ & 0.0461 & $33.6892^{* * *}$ & 843 \\
\hline 100 days estimation window & $-0.8193^{*}$ & -0.0634 & $35.9783^{* * *}$ & 920 \\
\hline 400 days estimation window & $-0.8797^{* *}$ & -0.0030 & $34.7241^{* * *}$ & 743 \\
\hline Daily return boundary: $+/-50 \%$ & $-0.9955^{* *}$ & 0.1128 & $34.9505^{* * *}$ & 1,010 \\
\hline Pennystock & $-0.9576^{* *}$ & 0.0749 & $33.7617^{* * *}$ & 856 \\
\hline Standard Industrial Classification (SIC) & $-0.9875^{* * *}$ & 0.1048 & $33.0579^{* * *}$ & 1,331 \\
\hline
\end{tabular}

This table reports cumulative average abnormal stock returns for the main event window [-1,1] from different robustness tests for aggregated U.S. (upper part) and Chinese tariff rounds (lower part). Baseline represents the results from our analysis of the aggregated tariff rounds between U.S. and China as reported in Tables 8 and 9. The Carhart four-factor model extends the three-factor model of Fama-French by a momentum factor for the asset pricing of stocks (Fama and French, 1993; Carhart, 1997). The 100 days estimation window and 400 days estimation window robustness tests vary the length of the estimation window to 100 and 400 trading days, respectively. Since we restrict our analysis by a daily return boundary of $+/-25 \%$ and by omitting pennystocks, we allow for a doubling of the boundary (Daily return boundary: $+/-50 \%$ ) and the consideration of pennystock companies (Pennystock) in two further robustness checks. Finally, we replace the six-digit matching identifier(North American Industry Classification System) by the four-digit Standard Industrial Classification system. The first column shows the CAARs from each robustness check. The significance of the CAARs is tested with the GRANK t-test. Difference shows the difference between CAARs from respective robustness tests and those from our aggregated tariff round analysis (Baseline). The difference between the CAARs is tested with the difference in means t-test. ' $\%>0$ ' is the percentage of positive CAARs for the main event window [-1,1]. Significances are tested with Pearsons chi-squared test of equal proportions. $N$ denotes the number of observations. ${ }^{* * *}, * *, *$ indicate statistical significance at the one-, five- and ten-percent level. 
Table 19: Sector analysis

\begin{tabular}{lcccccc}
\hline \hline & \multicolumn{2}{c}{ U.S. tariff rounds against China } & \multicolumn{3}{c}{ Chinese tariff rounds against U.S. } \\
\hline & CAAR $_{[-1,1]}($ in $\%)$ & $\%>0$ & $\mathrm{~N}$ & CAAR $_{[-1,1]}($ in $\%)$ & $\%>0$ & $\mathrm{~N}$ \\
\hline Consumer Discretionary & -0.6894 & $39.6396^{* *}$ & 111 & 0.3479 & 50.0000 & 78 \\
Consumer Staples & -0.6719 & $39.6396^{* *}$ & 111 & 0.9193 & 56.4103 & 78 \\
Energy & -0.9608 & $29.2683^{* * *}$ & 123 & -2.2116 & $20.5357^{* * *}$ & 112 \\
Health Care & $-1.4206^{* * *}$ & $28.7234^{* * *}$ & 188 & $-0.7400^{*}$ & $34.4156^{* * *}$ & 154 \\
Industrials & $-0.6897^{*}$ & $36.2025^{* * *}$ & 395 & $-1.2545^{*}$ & $28.2353^{* * *}$ & 170 \\
Information Technology & $-1.4917^{* * *}$ & $28.2123^{* * *}$ & 358 & $-0.5837^{*}$ & $34.4000^{* * *}$ & 125 \\
Materials & $-1.2685^{* *}$ & $30.7692^{* * *}$ & 169 & $-1.6853^{*}$ & $29.3578^{* * *}$ & 109 \\
\hline \hline
\end{tabular}

This table shows cumulative average abnormal stock returns (CAARs) for the main event window [-1,1] across different sectors. The left side reports CAARs according to the aggregated U.S. tariff rounds against China, while the right side presents CAARs according to aggregated Chinese tariff rounds against the United States. The sectors are identified by the Global Industry Classification Standard (GICS) system developed by MSCI and Standard \& Poor's. The significances of the CAARs are tested with the GRANK t-test. The difference between the CAARs is tested with the difference in means t-test. ' $\%>0$ ' is the percentage of positive CAARs within the $[-1,1]$ event window. Significances are tested with Pearsons chi-squared test of equal proportions. $N$ denotes the number of observations. ${ }^{* * *},{ }^{* *},{ }^{*}$ indicate statistical significance at the one-, five- and ten-percent level. 


$$
\mathrm{CAAR}_{[-1,1]}(\text { in } \%) \quad \%>0 \quad \mathrm{~N}
$$

Panel A: Tariff rate

U.S. tariff rounds against China: Firms grouped by tariff rate

$\begin{array}{llll}\text { Above } 10 \% & -1.4209^{* * *} & 29.9048^{* * *} & 525 \\ 10 \% \text { or lower } & -0.8354^{* * *} & 33.7755^{* * *} & 980 \\ \text { Difference } & -0.5855^{* * *} & & \end{array}$

Chinese tariff rounds against U.S.: Firms grouped by tariff rate
Above 10\%
$-1.1760^{*}$
$34.2995^{* * *}$
207
$10 \%$ or lower
$-0.7872^{*}$
$33.9623^{* * *}$
636
Difference
$-0.3888^{*}$

\section{Panel B: Tariff announcement (baseline) vs. tariff increase}

\section{U.S. tariff rounds against China}

$\begin{array}{lccc}\text { Announcement } & -1.0397^{* * *} & 32.4252^{* * *} & 1,505 \\ \text { Increase } & -0.4207 & 44.7332^{* * *} & 731 \\ \text { Difference } & -0.6190^{* * *} & & \end{array}$

Chinese tariff rounds against U.S.

$\begin{array}{lccc}\text { Announcement } & -0.8827^{* *} & 34.0451^{* * *} & 843 \\ \text { Increase } & -0.0422 & 51.6484 & 91 \\ \text { Difference } & -0.8405^{* *} & & \end{array}$

\section{Panel C: First announcement of a specific classification code (NAICS)}

\section{U.S. tariff rounds against China}

First announcement

$$
\begin{aligned}
& -1.2079 * * * \\
& -0.9798 * * * \\
& -0.2281
\end{aligned}
$$$$
30.1266^{* * *}
$$

Further announcement

$33.2432^{* * *}$

Difference

Chinese tariff rounds against U.S.

$\begin{array}{llll}\text { First announcement } & -1.5314^{*} & 25.8929^{* * *} & 112 \\ \text { Further announcement } & -0.7833^{* *} & 35.2941^{* * *} & 731 \\ \text { Difference } & -0.7481^{* *} & & \end{array}$

This table reports cumulative average abnormal stock returns (CAARs) for the main event window [-1,1] across different tariff characteristics, which are described in detail in Table 3. The significance of the CAARs is tested with the GRANK t-test. The differences between CAARs are tested with the difference in means t-test. ' $\%>0$ ' is the percentage of positive CAARs in the event window [-1,1]. Significances are tested with Pearsons chi-squared test of equal proportions. $N$ denotes the number of observations. $* * *, * *, *$ indicate statistical significance at the one-, fiveand ten-percent level. 


\begin{tabular}{lccc}
\hline \hline & $\mathrm{CAAR}_{[-1,1]}($ in $\%)$ & $\%>0$ & $\mathrm{~N}$ \\
\hline \multicolumn{2}{l}{ Panel A: U.S.-China trade balance per classification code (NAICS) } \\
U.S. tariff rounds against China & & 839 \\
Trade deficit & $-0.6557^{* * *}$ & $37.1871^{* * *}$ & 567 \\
Trade surplus & $-1.6011^{* * *}$ & $26.8078^{* * *}$ & \\
Difference & $0.9454^{* * *}$ & & 408 \\
Chinese tariff rounds against U.S. & & 353 \\
Trade deficit & $-0.7092^{*}$ & $36.2745^{* * *}$ & \\
Trade surplus & $-0.9206^{* *}$ & $33.4278^{* * *}$ & \\
Difference & 0.2114 & & \\
\hline
\end{tabular}

Panel B: Imports from China

U.S. tariff rounds against China

Importing firms

$-1.2056^{* * * *}$

$30.5239^{* * *}$

878

Non-importing firms

$-0.8469^{* * *}$

$34.4595^{* * *}$

592

Difference

$-0.3587^{* *}$

Chinese tariff rounds against U.S.

Importing firms

$$
-1.1177^{* *}
$$

$33.7004^{* *}$

454

Non-importing firms

$-0.7189^{* *}$

$34.0483^{* * *}$

373

Difference

$-0.3988^{*}$

\section{Panel C: Exports to China}

\section{U.S. tariff rounds against China}

Exporting firms

Non-exporting firms

Difference
$-1.2304^{* * *}$

$30.4054^{* * *}$

888

$-0.8029^{* * *}$

$34.7079^{* * *}$

582

\section{Chinese tariff rounds against U.S.}

Exporting firms

Non-exporting firms

Difference

$-1.0099^{* *}$
$-0.8155^{* *}$
-0.1940

473

354

This table reports cumulative average abnormal stock returns (CAARs) for the main event window [-1,1] across different trade characteristics, which are described in detail in Table 3. The significance of the CAARs is tested with the GRANK t-test. The differences between CAARs are tested with the difference in means t-test. ' $\%>0$ ' is the percentage of positive CAARs in the event window [-1,1]. Significances are tested with Pearsons chi-squared test of equal proportions. $N$ denotes the number of observations. ***,**,* indicate statistical significance at the one-, five- and ten-percent level. 


$$
\mathrm{CAAR}_{[-1,1]}(\text { in } \%) \quad \%>0 \quad \mathrm{~N}
$$

Panel A: Firm size

U.S. tariff rounds against China: Firms grouped by market capitalization
Above median
$-1.0375^{* * *}$
$31.1170^{* * *}$
752
Below median
$-1.0334^{* * *}$
$33.7766^{* * *}$
752
Difference
$-0.0041$

Chinese tariff rounds against U.S.: Firms grouped by market capitalization
Above median
$-0.5099$
$36.3420^{* * *}$
421
Below median
$-1.2547^{* * *}$
$31.7536^{* * *}$
422
Difference
$0.7448 * * *$

\section{Panel B: Performance}

\section{U.S. tariff rounds against China: Firms grouped by earnings per share}
Above median
$-0.9840 * * *$
$32.5798^{* * *}$
752
Below median
$-1.0952^{* * *}$
$32.2709^{* * *}$
753
Difference
0.1112

Chinese tariff rounds against U.S.: Firms grouped by earnings per share
Above median
$-0.6137$
$38.4798^{* * *}$
421
Below median
$-1.1510 * * *$
$29.6209^{* * *}$
422
Difference
$0.5373^{* *}$

\section{Panel D: Rating}

U.S. tariff rounds against China: Firms grouped by rating status

$\begin{array}{lccc}\text { Investment grade } & -1.0174^{* * *} & 27.5000^{* * *} & 440 \\ \text { Non-investment grade } & -1.2303^{* * *} & 31.0734^{* * *} & 354 \\ \text { Difference } & 0.2129 & & \end{array}$

U.S. tariff rounds against China: Firms grouped by rating status

$\begin{array}{lccc}\text { Investment grade } & -0.5430 & 36.5957^{* * *} & 235 \\ \text { Non-investment grade } & -1.0739^{*} & 30.8458^{* * *} & 201 \\ \text { Difference } & 0.5309^{*} & & \end{array}$

This table reports cumulative average abnormal stock returns (CAARs) for the main event window [-1,1] across different firm characteristics, which are described in detail in Table 3. The significance of the CAARs is tested with the GRANK t-test. The differences between CAARs are tested with the difference in means t-test. ' $\%>0$ ' is the percentage of positive CAARs in the event window [-1,1]. Significances are tested with Pearsons chi-squared test of equal proportions. $N$ denotes the number of observations. $* * *, * *, *$ indicate statistical significance at the one-, five- and ten-percent level. 